\title{
An end-to-end coupled model ROMS-N(2)P(2)Z(2)D(2)- OSMOSE of the southern Benguela foodweb: parameterisation, calibration and pattern-oriented validation
}

\author{
Travers-Trolet Morgane ${ }^{1,{ }^{*}}$, Shin Yunne-Jai ${ }^{2,3}$, Field J. G. ${ }^{3}$
}

${ }^{1}$ IFREMER, Fishery Resources Lab, Boulogne Sur Mer, France.

2 IRD, Res Inst Dev, CRH Ctr Mediterranean \& Trop Fisheries Res, UMR Joint Res Unit EME Exploited Marine Ecosyst, Sete, France.

3 Univ Cape Town, Marine Res Inst, ZA-7925 Cape Town, South Africa.

*Corresponding author : Morgane Travers-Trolet, email address : mtravers@ifremer.fr

\begin{abstract}
:
In order to better understand ecosystem functioning under simultaneous pressures (e.g. both climate change and fishing pressures), integrated modelling approaches are advocated. We developed an endto-end model of the southern Benguela ecosystem by coupling the high trophic level model OSMOSE with a biophysical model (ROMS-N(2)P(2)Z(2)D(2)). OSMOSE is a spatial, multispecies, individual-based model simulating the whole life cycle of fish with fish schools interacting through opportunistic and sizebased predation. It is linked to the biogeochemical model through the predation process; plankton groups are food for fish and fish apply a predation mortality on plankton. Here we describe the two-way coupling between the models and follow a pattern-oriented modelling approach to validate the simulations. At the individual level, model outputs are consistent with observed diets for several species from small pelagic fish to top predatory fish, although biases emerge from underestimation of macrozooplankton and lack of vertical structure. At the population level, the seasonality of the size structure is similar between the model and data. At the community level, the modelled trophic structure is consistent with the knowledge available for this ecosystem. The structure of the foodweb is an emergent property of the model, showing trophic links between species, their strength and the strong connectivity observed. We also highlight the capacity of this model for tracking indicators at various hierarchical levels.
\end{abstract}

Keywords : individual-based model, model validation, pattern-oriented modelling, trophic interactions, two-way coupling 


\section{Introduction}

(1)

While the ecosystem approach to fisheries has been advocated for a decade (FAO 2003), a related concern has grown about the effects of global change on marine ecosystems. Climate change and overfishing have been proved to have combined impacts on marine ecosystems, so both drivers need to be considered simultaneously in analysing dynamics of marine ecosystems (Cury et al. 2008, Hsieh et al. 2008, Link et al. 2010, Travers-Trolet et al. in prep). Climate and fishing affect the dynamics of particular species, but they may also affect the entire food web, not only in terms of flux intensity, but also in terms of structure and dominant pathways (Shin et al. 2010). With the challenge to predict future impacts of global change, the use of innovative tools has been encouraged, and the development of end-to-end models is one of the tracks to follow (Travers et al. 2007, Rose et al. 2010, Fulton 2010). Existing methods also need to be improved to suitably address ecosystem dynamics in a changing environment and for predicting the combined effects of overfishing and global warming on marine food webs. Difficulties are encountered with non-mechanistic statistical models for producing robust predictions because we are facing completely new situations of global change causing a lot of ecological surprises, such as unanticipated shifts or species collapses, which are associated with non-linear systems (Pine et al. 2009, Lindenmayer et al. 2010, Shin et al. 2010). In the current modeling landscape, there is a limited but increasing choice of existing mechanistic models for assessing the effects of both fishing and environment (Fulton 2010). Applications of the ecosystem model Ecopath with Ecosim (Walters et al. 1997) have started to address the effects of both fishing and climate change in a more explicit way (Field et al. 2006, Araújo et al. 2006, Mackinson 2009), but as the trophic control of interactions between species is fixed (through vulnerability coefficients), this model is probably not flexible enough to address the effects of important changes in climate and fishing drivers which may induce shifts in food web structure.

Still at a pioneering stage, end-to-end models aim to represent the whole ecosystem in its environment. In such models, physical and biological processes are integrated at different scales 
and two-way interactions are considered between ecosystem components. Finally these models account for the dynamic forcing effect of climate and human impacts at multiple trophic levels and in an explicit way (Travers et al. 2007). Our objective is to develop such an end-to-end model by coupling two distinct models, one of low trophic levels ( $L T L)$ and one of high trophic levels $(H T L)$, to address combined effects of global changes on the structure and function of marine food webs.

The coupled model described here represents the 3D dynamics of physical variables such as currents, salinity and temperature. It also represents planktonic groups from phytoplankton to large zooplankton, and finally fish species with all life stages of fish from eggs and larvae up to adults being explicitly represented and which can be subjected to fishing activity. Thus, the major components of the ecosystem are represented as well as major physical and anthropogenic forcing factors. Moreover, the effects of these drivers can propagate up and down the food web through the predation process, which is represented in both models and in linking them, making all trophic levels susceptible. Finally, because predation is modelled as an opportunistic process, the food web structure can change under pressure of global changes and provides an emergent property of the model.

The objective of the paper is to thoroughly describe the different steps involved in the development and application of the end-to-end model of the southern Benguela ecosystem. In a first part the coupled model is described, focusing on the plankton model ROMS- $N_{2} P_{2} Z_{2} D_{2}$ first, 
then on the multi-species model OSMOSE and finally on the two-way coupling process linking both models. Then we present the method used to calibrate the model, based on evolutionary algorithms. We validate the model applied by comparing output with independent data from the southern Benguela ecosystem at multiple levels, following the pattern-oriented modeling approach advocated by Grimm et al. (2005). Finally we discuss the model output and its potential for studying marine food webs and assessing the combined effects of global change on ecosystems. A separate paper uses the coupled model to assess the combined effects of fishing and climate change on the Benguela ecosystem (Travers-Trolet et al. in prep).

\section{Materials and Methods}

At one end of the coupled model, the LTL model is a biogeochemical model representing the dynamics of phytoplankton and zooplankton communities split into boxes according to their size and forced by a hydrodynamic model. At the other end, the HTL model OSMOSE is a sizebased and multispecies model in which no pre-determined diets are prescribed, allowing the food web to emerge from local predation interactions. Developed and applied separately to the southern Benguela ecosystem, these models have undergone some changes in order to couple them. We present these changes here.

\section{The LTL model: ROMS- $\underline{N}_{2} \underline{\underline{P}}_{2} \underline{Z}_{2} \underline{\mathrm{D}}_{2}$}

ROMS (Regional Ocean Modeling Systems, Shchepetkin and McWilliams 2005) is a three-dimensional hydrodynamic model that has been applied to the southern Benguela system (Penven et al. 2001). The "Plume" configuration uses a curvilinear grid extending from the Agulhas Bank on the South coast of South Africa to Hondeklip Bay $\left(30^{\circ} \mathrm{S}-17^{\circ} \mathrm{E}\right)$ on the West coast (Figure 1A), with a horizontal resolution ranging from $18 \mathrm{~km}$ at the coast to $31 \mathrm{~km}$ offshore, 
and 20 sigma layers vertically. The model is forced by monthly climatology fields derived from the

127 Comprehensive Ocean-Atmosphere Data Set (COADS) (Da Silva et al. 1994), including wind

128 stress and heat flux at the sea surface and runs with a time step of 20 minutes.

ROMS has been coupled to a biogeochemical model of plankton by Koné et al. (2005), in

131 are each split into two compartments mostly according to size. Ammonium and nitrate form the

132 two nutrient pools, micro- and meso-phytoplankton and micro- and meso-zooplankton

133 compartments respectively represent the dominant communities of flagellates and diatoms for

134 phytoplankton, and ciliates and copepods for zooplankton; the detritus box is split into slow

135 (small) and fast (large) sinking detritus (Figure 2).

136 This $\mathrm{N}_{2} \mathrm{P}_{2} \mathrm{Z}_{2} \mathrm{D}_{2}$ model simulates fluxes of nitrogen between compartments expressed in $137 \mathrm{mmol}$. N.m ${ }^{-3}$. Nitrogen is the classic currency used in plankton models as it is generally 138 considered to be the main limiting nutrient to primary production and allows one to disentangle 139 new and regenerated production (Fasham et al. 1990). Furthermore, Andrews and Hutchings 140 (1980) and Probyn (1992) have shown nitrogen to be the limiting nutrient in the southern 141 Benguela ecosystem. Phytoplankton growth rate $\left(\mu_{p}\right)$ is limited by three factors: light intensity 142 (PAR: photosynthetically available radiation), temperature $(T)$ and nutrients concentration $(M)$, as 143 expressed in the following equations.

$$
\mu_{p}=\mu_{p}(P A R, T) \cdot \mu_{p}(N)
$$

146

$$
\mu_{p}(\mathrm{~N})=\frac{\left[\mathrm{NH}_{4}\right]}{k_{\mathrm{NH}_{4}}+\left[\mathrm{NH}_{4}\right]}+\left(\frac{\left[\mathrm{NO}_{3}\right]}{k_{\mathrm{NO}_{3}}+\left[\mathrm{NO}_{3}\right]} \cdot \frac{k_{N H_{4}}}{k_{\mathrm{NH}_{4}}+\left[\mathrm{NH}_{4}\right]}\right)
$$


149 with $\alpha$ being the initial slope of the phytoplankton-irradiance curve, $a$ and $b$, parameters of the

150 light-saturated growth, and $\mathrm{k}_{\mathrm{NH} 4}$ and $\mathrm{K}_{\mathrm{NO} 3}$ being the half-saturation constants for ammonium and 151 nitrate uptake respectively.

152 Light limitation (Equation 2) depends on the PAR, calculated at each time step and is spatially 153 variable according to the surface irradiance and the chlorophyll concentration. It also varies 154 according to temperature through the $V_{p}$ term, which is the light-saturated growth. Equation 3 155 represents nutrient limitation, following Michaelis-Menten formulation, with inhibition of nitrate $156\left(\mathrm{NO}_{3}\right)$ uptake by high concentration of ammonium $\left(\mathrm{NH}_{4}\right)$. Phytoplankton groups also undergo loss 157 by predation due to grazing zooplankton, as well as a constant natural mortality rate $\left(m_{p}\right)$.

158 Zooplankton growth rate $\left(g_{z}\right)$ depends on the food ingested according to a Holling type II 159 function (Equation 4).

$$
g_{z}=g_{\max } \cdot \frac{\sum e_{z i} \cdot\left[F_{i}\right]}{k_{z}+\sum e_{z i} \cdot\left[F_{i}\right]}
$$

161 Where $g_{\max }$ is the maximum grazing rate, $e_{z i}$ are preference coefficients of zooplankton $z$ for each 162 available prey $i$, reflecting the difference of filtration efficiencies, $k_{z}$ is the half-saturation constant 163 for the predator ingestion, and $F_{i}$ is the concentration of prey $i$. Ciliates are considered 164 herbivorous and prey upon both phytoplankton groups (with a preference for flagellates) whereas 165 copepods are considered omnivorous and thus can prey upon flagellates, diatoms and ciliates. 166 Excretion is modelled by a constant flux of nitrogen from zooplankton to the ammonium pool. 167 Processes of egestion and natural mortality (mortality rate $m_{z}$ ) are represented by a constant loss 168 from large and small zooplankton towards large and small detritus boxes, respectively.

169 Detritus boxes are filled from natural mortalities of the 4 living groups and egestion from 170 zooplankton groups (faecal pellets). Remineralization rates are considered constant and lead to 171 nitrogen fluxes from detritus boxes to the ammonium pool, which is in turn transformed into nitrate 172 at a constant nitrification rate (Koné et al. 2005). The differential equations for all biological 173 compartments can be found in appendix A. Parameters values are from Koné et al. (2005) and 174 summarized in Table 1. 

and the circulation patterns provided by the hydrodynamic model ROMS with a 20-minutes time 177 step. The model is initialized with a $\mathrm{NO}_{3}$ spatial distribution from Conkright et al. (1994), whereas 178 the initial conditions of all other groups are constant: $0.1 \mathrm{mmol}$. N.m ${ }^{-3}$ for $\mathrm{NH}_{4}, 0.04 \mathrm{mmol}$. N.m ${ }^{-3}$ 179 for flagellates, $0.06 \mathrm{mmolN} \cdot \mathrm{m}^{-3}$ for diatoms, $0.04 \mathrm{mmol} . \mathrm{N} \cdot \mathrm{m}^{-3}$ for both groups of zooplankton and

$180 \quad 0.02 \mathrm{mmol} . \mathrm{N} \cdot \mathrm{m}^{-3}$ for both detritus boxes. In this configuration, the model stabilizes after 2 years 181 of spin-up (Koné et al. 2005). The biological part of the model has been calibrated to an average year (corresponding to forcing climatology) for the southern Benguela, with a particular interest on

183 simulating the spatio-temporal seasonal dynamics (Koné et al. 2005). For this study, the 184 compartments of interest of this model consist in the living groups, namely flagellates, diatoms, 185 ciliates and copepods, as they are used as a food supply for the HTL model.

\section{The HTL model: the multi-species model OSMOSE} Exploitation) aims at simulating fish individuals interacting via opportunistic size-based predation

192 (Shin and Cury 2001a, 2004). The basic unit of this model is a super-individual representing a 193 school of organisms of the same size, same age and belonging to the same species. These 194 schools interact through opportunistic predation, based on spatio-temporal co-occurrence and size adequacy between a predator and its prey. Because of this opportunism, no a priori food

196 web or diet matrix is set, but they emerge from local trophic interactions. Predation and marine 197 food webs are hence modelled as being intrinsically variable, a property that is empirically 198 supported in various ecosystems (Bax 1998), and in the southern Benguela ecosystem (e.g. Punt 199 et al. 1992, Van der Lingen 2002). This is an interesting and important feature of the model when 200 addressing effects of global change on marine ecosystems which may trigger changes and shifts 201 in the structure of the food webs, (Travers et al. 2009), hence potentially leading to ecological 202 surprises such as species alternations, collapses or expansions (Shin et al. 2010). 
In the initial version of OSMOSE (Shin and Cury 2001a, 2004), fish schools were split

204 into piscivorous and non-piscivorous fish according to their age and taxonomy. The biomass of 205 non-piscivorous fish was constrained by a carrying capacity parameter, which represented the 206 maximum biomass of planktivorous fish, i.e. sustainable by an implicit plankton biomass. Thanks 207 to the coupling with an explicit plankton model, the carrying capacity term no longer exists, 208 neither do the piscivorous and planktivorous split. Instead, an individual can feed on both 209 plankton and fish according to a feeding size range defined by a maximum and minimum size 210 ratio between a predator and its prey.

211 In order to facilitate the coupling with the LTL model, the time step of OSMOSE initially 212 set to 6 months has been reduced to a 2-week period, as a compromise between plankton 213 dynamics which have a much higher turnover rate (modelled with a time step of 20 minutes) and 214 process formulation and associated knowledge for HTL. One time step in the coupled model is 215 composed of the following processes (figure 2).

\section{a. Spatial distribution}

In this two-dimensional model, because of the poor knowledge of the determination of fish movement and its parameterization, particularly in a multispecies context, the horizontal distribution of fish is driven by presence/absence maps provided as input. Schools are randomly

221 distributed within the distribution maps computed per species, age and per season (Shin et al.

222 2004; appendix B). There are two types of movement in the model: the distribution maps 223 (Appendix B) give seasonal life history migrations, and when the distribution map of the 224 population does not change from one time step to the next, schools move randomly to an 225 adjacent cell of the 2D spatial grid (random walk).

230 HTL fish that are not explicitly modelled, birds and mammals) (Equation 5). 
The mortality $M_{0}$ applied to the first stage of fish (corresponding to eggs and first-feeding larvae) is treated differently to take into account the higher mortality rates compared to other fish stages. The processes involved are numerous (e.g., non-fertilization of eggs, starvation of first-

235 feeding larvae, advection, sinking, predation by unrepresented organisms) and because of the 236 lack of quantitative knowledge concerning these larval mortalities, these parameters are 237 estimated during the calibration process.

\section{c. Predation}

Predation is opportunistic and a predator can prey on any organisms present in its own cell provided they have a suitable size, i.e., comprised between a maximum and minimum size

242 relatively to predator body length. These values defining a feeding size range are computed from

243 literature when available or derived from diets and species mean size (Table 2). Two sets of size ratio can be provided for the juvenile and adult stages of a given species if the feeding behavior 245 changes ontogenetically (e.g., passive feeding of small particles for adult sardine versus active 246 feeding of large ones for juveniles, van der Lingen 1998), or if a morphological change occurs 247 (e.g., gill raker development, morphometric differences between larvae and juveniles/adults). The 248 amount of prey eaten depends on the local relative biomass of prey and on the maximum food 249 edible by the predator (table 3). An explicit mortality rate is applied to prey schools: if enough prey 250 are present the predator feeds upon them uniformly until it reaches satiation, otherwise it depletes 251 all prey available but without reaching satiation. At the end of this process a predation efficiency $\xi_{i}$ 252 is calculated for each school $i$ as the ratio between the biomass of prey eaten and the maximum 253 food edible. The order at which predator schools feed is randomly drawn at each time step.

\section{d. Growth}

Predation is considered successful enough to allow growth when the predation efficiency 257 is higher than a critical value $\xi_{\text {crit }}$ representing the amount of food required for fulfilling 258 maintenance. In this case, the body size of organisms increases following an adaptation of the 
von Bertalanffy model. The growth rate in length $\Delta L_{i, t}$ of the school $i$ at time $t$ depends on

260 predation efficiency $\xi_{i}$ (Equation 6), with the median value of the interval [ $\xi_{\text {crit, }}, \xi_{\max }=1$ ]

261 corresponding to the von Bertalanffy growth rate. Actual growth rates hence vary between 0 and

262 twice the mean length increase $\Delta L$, calculated from the von Bertalanffy model. The individual

263 weight $W_{i, t}$ is computed from length according to the allometric relationship $W_{i, t}=c L_{i, t}^{b}$, with $b$ and

$264 \quad c$ two species-specific parameters to be provided in input of the model.

$$
\left\{\begin{aligned}
L_{i, t}=0 & \text { if }{ }_{i}<c_{\text {crit }} \\
L_{i, t}=\frac{2 L}{1 \quad \text { crit }}\left({ }_{i} \quad \text { crit }\right) & \text { if }{ }_{i}>_{\text {crit }}
\end{aligned}\right.
$$

\section{e. Starvation}

273 to a decrease of the school abundance (Equation 8).

$$
\begin{aligned}
& M=\frac{M_{\text {max }}}{c r i t} \cdot{ }_{i}+M_{\text {max }} \\
& N_{i, t+\Delta t}=N_{i, t} \cdot e^{-\Delta t \cdot M \xi}
\end{aligned}
$$

\section{f. Fishing}

The fishing process consists of reducing school abundance by applying a species279 specific fishing mortality rate $F$ to any school older than a recruitment age specified for each

280 species (Table 3 ). This mortality is homogeneous spatially but can vary over time following a 281 fishing seasonality provided as input for each species (see appendix C). The amount of fish 282 caught is determined by equation 9 . 


$$
C_{i, t+\Delta t}=N_{i, t}\left(1-e^{-\Delta t \cdot F(t)}\right)
$$

\section{g. Reproduction}

At the end of the time step, the reproduction process allows one to introduce new schools at the egg stage in the model. Following equation 10 , the quantity of eggs released $N_{0, t}$ depends on the spawning biomass (with sex-ratio set to 1:1), i.e. the biomass of individuals older than age at maturity $\left(A_{\text {mat }}\right)$, and the fecundity parameter $\Phi$ which varies according to a spawning 290 seasonality provided as input (see appendix C).

$$
N_{0, t}=\Phi(t) \cdot \frac{1}{2} \sum_{a>A_{\text {mat }}} B_{a, t}
$$
Shin et al. (2004) and for the 1990s period by Travers et al. (2006). In the present version, the grid extends from the mouth of Orange River $\left(16^{\circ} \mathrm{E}-28.8^{\circ} \mathrm{S}\right)$ to the Agulhas Bank, at Cape St Francis longitude $\left(24.4^{\circ} \mathrm{E}-37.7^{\circ} \mathrm{S}\right)$ and is divided into cells of $0.15^{\circ} \times 0.15^{\circ}$ (Figure 1B). The set of species chosen to represent the HTL community of the southern Benguela has been slightly modified since the application by Travers et al. (2006), the main change being the introduction of a euphausiid species. Indeed the plankton model used for the coupling only considers copepods as large zooplankton, but euphausiids have been shown to be a major trophic link in the southern Benguela ecosystem (Pillar 1987). The species considered are now composed of one crustacean

302 group: euphausiids (represented by Euphausia lucens) and 10 fish species: anchovy (Engraulis 303 encrasicolus), sardine (Sardinops sagax), redeye round herring (Etrumeus whiteheadi), 304 lanternfish (Lampanyctodes hectoris), lightfish (Maurolicus muelleri), horse mackerel (Trachurus 305 trachurus capensis), shallow water hake (Merluccius capensis), deep water hake (Merluccius 306 paradoxus), snoek (Thrysites atun) and silver kob (Argyrosomus inodorus). They are 307 representative of the HTL community in terms of biomass, catches and trophic position. The 308 predation by other HTL species is accounted for implicitly in the natural mortality coefficients of 309 the modelled species; this also accounts for competition with non-explicit predators. The 
biological parameters used for these species are computed in Table 2 and 3, and information on their spatial distributions can be found in appendix B.

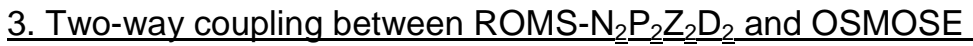

Linking ROMS- $\mathrm{N}_{2} \mathrm{P}_{2} \mathrm{Z}_{2} \mathrm{D}_{2}$ and OSMOSE is realized through the predation process: plankton biomass serves as a potential prey field for HTL organisms, which in turn are responsible for a predation mortality applied to plankton groups (Figure 2). We use the same predation process as in OSMOSE model, i.e. an opportunistic size-based predation as described above. Contrary to fish schools which are characterized by individual fish sizes in OSMOSE, plankton groups do not present a single body size but rather a size range (Table 4). Thus, we consider the edible proportion of one plankton group to be equal to the proportion of its size range suitable for the predator over its full size range. Moreover, because of numerous processes such as turbulence, stratification, diel migration, and vertical distribution, the entire biomass of plankton is not available for fish and euphausiids in marine ecosystems. Thus, in the coupled model, only part of plankton biomass, which is modelled in 3D, is considered available to HTLs which are modelled in 2D. As little quantitative information was found on the availability of plankton biomass to fish, the proportion of plankton biomass accessible to fish predation (one accessibility coefficient $a_{p}$ per plankton group $p$ ) were estimated through calibration of the coupled model.

Whereas predation mortality consists of the explicit removal of the prey individuals in OSMOSE, the predation on the plankton groups of the LTL model is modeled through a spatial field of predation mortality rate for each plankton group. In each cell $(x, y)$ and for each plankton group $(p)$, the HTL-induced mortality rate $m_{H T L}$ is computed as the biomass of plankton eaten during a time step $B E_{\Delta t}$ over the available biomass $B$ (Eq 11) multiplied by the time step $\Delta t$ over which the integration of the mortality rate is computed. Because the biomass of plankton eaten during a time step can vary between 0 and the maximum plankton biomass available $\left(a_{p} \cdot B\right)$, the $\mathrm{HTL}$-induced mortality rate will be comprised within $\left[0 ; a_{p} / \Delta t\right]$. 


$$
m_{H T L}(x, y, t+\Delta t, p)=\frac{B E_{\Delta t}(x, y, p)}{\Delta t \cdot B(x, y, t, p)}
$$

340 A residual natural mortality rate of plankton $m_{\text {res }}$ remains and is assumed to be constant over 341 space and time. It is set to the initial mortality rate $m_{p}$, which is used in the standalone ROMS$342 \quad \mathrm{~N}_{2} \mathrm{P}_{2} \mathrm{Z}_{2} \mathrm{D}_{2}$ model (Table 4) minus the median of the variable HTL-induced predation mortality, i.e. $343 a_{p} / 2 \Delta t$. This constant part of the mortality applied to plankton $\left(m_{p}-a_{p} / 2 \Delta t\right)$ represents implicitly 344 other sources of mortality such as predation by non-modeled organisms (e.g., salps, gelatinous 345 zooplankton), senescence and starvation mortality. According to this formula (Eq 12), the total 346 mortality rate $m(x, y, t+\Delta t, p)$ applied to the plankton group $p$ can vary between the limits $\left[m_{p}-\right.$ $347 a_{p} / 2 \Delta t ; m_{p}+a_{p} / 2 \Delta t$, and thus can be either higher or lower than the initial mortality rate, 348 depending on the predation pressure applied by HTL organisms.

$$
m(x, y, t+\Delta t, p)=m_{H T L}+m_{r e s}=\frac{B E_{\Delta t}(x, y, p)}{\Delta t . B(x, y, t, p)}+\left(m_{p}-\frac{a_{p}}{2 . \Delta t}\right)
$$
(mmolN. $\mathrm{m}^{-3}$ versus wet weight), plankton concentrations are vertically integrated and transformed into biomass of available food during a time step using conversion factors for currencies (Table 4). The difference in the horizontal grids used in both models involves bilinear spatial interpolation from the LTL grid to the HTL one for plankton biomass field, and in the other way for predation mortality field. Technical implementation of this coupling is realized through exchange of files of plankton biomass and predation mortality rate between OSMOSE (developed in Java) and

358 ROMS- $N_{2} P_{2} Z_{2} D_{2}$ (developed in Fortran). The models are run sequentially at each time step, as represented in the scheduling chart (Figure 3). 
The coupled model is calibrated so that the HTL species biomasses reach mean values observed in the southern Benguela during the 1990-1997 period (called reference biomasses,

365 table 5). To do so, we use an ad hoc evolutionary algorithm method (Duboz et al. 2010) applied 366 to a set of 15 unknown parameters, comprised of the 11 larval mortalities $\left(M_{0}\right)$ of HTL species 367 and 4 availability coefficients $\left(a_{p}\right)$ for plankton groups. The reference biomasses of HTL species 368 are associated with valid intervals (within which biomass value is considered acceptable) 369 accounting for variability and uncertainty of biomass estimates over the modeled period (table 5, 370 Shannon et al. 2003). best set of unknown parameters (called genotype) which allows the simulated biomasses (called 374 phenotype) to be the closest possible to the reference biomasses. Based on evolutionary theory, 375 this method uses the principles of reproduction (crossover and mutation) and adaptive selection 376 of the best genotypes over the generations.

The first generation is initialized with 200 genotypes consisting of 11 larval mortalities sampled within a uniform distribution $\left(\left[0 ; 7\right.\right.$ week $\left.\left.^{-1}\right]\right)$ and 4 availability coefficients sampled uniformly within [0;1]. Each genotype is evaluated using a composite fitness function which is high when the simulated biomass is inside the valid interval and increases proportionally as the simulated biomass gets closer to the reference biomass (see Duboz et al. 2010 for details).

At each generation, the best genotype is selected and used to create an optimal genotype. Combined with the 50 best genotypes, the optimal one is used to form 100 children, 384 the new genotypes replacing half of the population. Every 20 generations, a naïve strategy tests genotypes in the entire search space in order to avoid local minima. We run the evolutionary algorithm until convergence, i.e. when only genotypes with a high fitness maintain themselves.

\section{Model run}


The HTL model is initialized with a coarse age-structure for each species and a random distribution of schools within their distribution area. The OSMOSE model is run for 30 years with 392 plankton as a prey field in order to stabilize (forcing mode during spin-up), before being run in a two-way coupling mode for 15 years. As the OSMOSE part of the coupled model is stochastic, 10 simulations have been conducted and averaged. Only outputs from the two-way coupling mode are considered, i.e. after spin-up time.

396

\section{Validation via the pattern-oriented modeling (POM) approach}

To test the reliability of the coupled model, we follow the pattern-oriented modeling (POM) approach proposed by Grimm et al. (2005), which states that model outputs should be validated with patterns observed at different levels. These patterns must come from independent data, i.e. not having been used during the development process of the model, or during calibration. Before running the coupled model, observed patterns were selected a priori at the individual level, the population level and the community level.

At the individual level, we use diet data of different fish species expressed in percentage of mass of prey species, and look at changes in diet over space. In the model, the predation process is opportunistic and individually-based only on size relationships (without any prey taxonomic preference). Therefore, a similarity in the prey species composition between emergent simulated diets and observed diets would participate to the structural validation of the model concerning the formulation of the predation process. We compare the diets of all species with the data collated by Shannon et al. (2003), where the diet matrix used as input to an Ecopath model comes from empirical studies of stomach contents by Pillar and Barange (1993, 1995, 1997), Punt et al. (1992), Pillar and Wilkinson (1995), inter alia, and synthesizes the data available for this ecosystem over the 1990s. The model outputs are also compared with more detailed observations coming from Griffiths (2002) and concerning snoek diet for medium-sized individuals $(50-74 \mathrm{~cm})$, in the western part of the system (upwelling area, north of $34.4^{\circ} \mathrm{S}$ ) and in the southern 
part (south of $\left.34.4^{\circ} \mathrm{S}\right)$. These data were collected between 1994 and 1997, thus representative of the simulated period.

At the population level, we confront model outputs with size data. To do so, we compare the temporal evolution of the mean length of anchovy landings with data provided by Fairweather et al. (2006) for the whole modeled area. As the model is set to represent the 1990-1997 period, we only use monthly data of the same years.

Finally, at the community level, we focus on trophic indicators to validate the food web structure, and we particularly compare the mean trophic levels (TLs) of species in the model with TLs provided by an independent model, Ecopath (Shannon et al. 2003). These TLs provided by Ecopath are data driven as they synthesize the species diets in input and the relative abundance of each species. In the present coupled model ROMS- $N_{2} P_{2} Z_{2} D_{2}-O S M O S E$, the trophic level is calculated for each school by considering an average turn-over rate of the tissues over 2 months (François Le Loc'h, pers. com., Trueman et al. 2005, Logan et al. 2006), i.e. with consideration of the food ingested in the last 2 months (or last 4 time steps), following Equation 13.

$$
T L_{\text {predator }, t+1}=\frac{\sum_{x=t-3}^{t} \Delta W_{x} *\left(1+\sum T L_{\text {prey }, x} * D C_{\text {prey }, \text { predator }, x}\right)}{\sum_{x=t-3}^{t} \Delta W_{x}}
$$

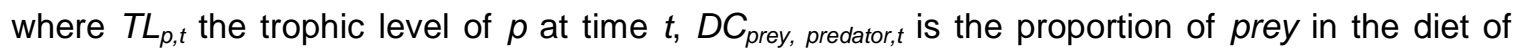
predator at time $t$, and $\Delta W_{t}$ is the weight increase of the predator during the time step $t$. The mean TL of a species corresponds to the average of the TLs of all schools of this species weighted by the schools' biomass. As a convention, we consider that the trophic level of eggs is similar to that of first-feeding larvae, and is set to 3 . We also consider that individuals which have not increased in size in the previous 2 months keep their previous TL. The TLs of plankton groups are constant and set to 1 for phytoplankton groups, to 2 for the herbivorous ciliates and to 2.5 for the omnivorous copepods (Table 4). 
445 Results

446

\section{Calibration}

The fitness produced as output from the evolutionary algorithm converges after 80 generations, with a value higher than 0.9 and with all the simulated biomasses situated within their valid intervals (Figure 4). From the $80^{\text {th }}$ generation, the best genotype simulated by the genetic algorithm improves slightly, allowing the simulated biomasses to be closer to the reference values. After 230 generations, the algorithm found 156 genotypes allowing all the species biomasses to stand within their valid intervals. To select the best set of parameters, we keep the ones providing the highest fitness and we search the best compromise by considering two other constraints: the set of parameters must result in the smallest variance of biomass among replicates of simulations and each parameter value must be the closest possible to the mode found by the evolutionary algorithm over the 156 valid genotypes (Figure 5). The final genotype that is selected corresponds to generation 229 and provides the parameter values for plankton availability coefficients and larval mortalities to be used for the reference simulations (tables 4 and 5).

Concerning the estimates obtained for the larval mortalities, we can note that the euphausiids' mortality value is very small. The two mesopelagic fish (lightfish and lanternfish) also display small larval mortalities (respectively 0.98 and 0.57 week $^{-1}$ ). The small pelagic fish (anchovy, sardine and redeye) show similar values of larval mortality, i.e. respectively $2.14,1.84$ and 1.92 week $^{-1}$. By contrast, the large fish species modeled have high values of larval mortalities, between 3 and 5 week $^{-1}$. We note that the width of the parameter distributions varies among species. For example, the larval mortality of snoek is more sensitive in the overall fit of simulated biomasses than the sardine larval mortality, which varies between 1.5 and 2.5 week $^{-1}$.

The availability coefficients estimated for plankton are quite low, especially for dinoflagellates $\left(5.7710^{-4}\right)$ but also for the other groups (diatoms: 0.0054 , ciliates: 0.0095 , 
copepods: 0.113 ), meaning, for example, that only $11.3 \%$ of the copepod production is available for HTL organisms during one time step.

\section{a. Comparison of diets (patterns at the individual level)}

\section{Validation of the southern Benguela simulation}

Diet data of small pelagic fish show that anchovy and redeye display similar diets, with mesozooplankton representing the major prey, and macrozooplankton being the second main prey (Figure 6). The pattern differs for sardine, which feeds equivalently on phytoplankton, microzooplankton and mesozooplankton. The simulated diet of sardine is similar to that found in the data, with the three prey types eaten in similar proportion (Figure 6). For anchovy and redeye, the model simulates too small a proportion of macrozooplankton in the diets $(10 \%$ instead of $35 \%$ ), but the results remain qualitatively realistic, i.e. the main prey of both species is mesozooplankton and the second prey in importance is euphausiids (belonging to the macrozooplankton group).

Observed diets of hakes illustrate the opportunism of these species (Figure 6). Adults of shallow water hake feed on horse mackerel, juvenile hakes, mesopelagic fish, anchovy, sardine, redeye and macrozooplankton. The diet of deep water hake is less diversified and consists of mesopelagic fish as the main prey, plus macrozooplankton, juvenile hakes and redeye. The output from the model shows that shallow water hake feeds upon small pelagic fish, mesopelagic fish, horse mackerel and hakes (Figure 6), as is observed in the data. However, the model simulates too large a proportion of small pelagic fish, and too small a proportion of hakes in the diet of shallow water hake. The main prey of deep water hake simulated by the model is mesopelagic fish, which is also the case in the data. The role of horse mackerel is also similar between the model and data, as it is a fairly important prey for shallow water hake but barely appears in deep water hake diet. The contribution of redeye and hake in the diet of deep water hake is similar between model output and data. The main difference concerns the 
macrozooplankton group which represents $20 \%$ of the observed diet, but is replaced by small pelagic fish in the model results.

When looking at the snoek diets (Figure 7), stomach contents data show a clear decrease of the importance of sardine as a prey from the South to the West coast. There is also a decrease in the importance of redeye, but an increase of euphausiids, anchovy and hake in the diet of snoek caught on the West coast. Simulated diets are different from the data, and do not reflect the dominance of sardine in the diet of snoek on the South coast. However, similar trends are observed between the two areas: there is a decrease of sardine and redeye importance in snoek diet on the West coast, as well as an increase of hake. The anchovy contribution decreases a little, but as they represented almost $25 \%$ of the diet on the South coast, they still account for a significant part of the diet on the West coast.

\section{b. Size-based patterns at the population level}

The mean length of anchovy observed in the monthly landings is presented in Figure 8 for each year of the period 1990-1997. This indicator displays a quite high interannual variability, especially from February to May, austral late summer to autumn. However, we note that on average, the mean lengths in the landings tend to be high in autumn and decrease in austral winter as new recruits appear. There are no data for the end of the year, but the mean length seems to have an increasing trend in the previous months. The model simulates a mean length of anchovy in the catch smaller on average than the mean length in observed landings (6.3 versus $8.1 \mathrm{~cm})$. However, the temporal evolution of this indicator is similar to the observations, i.e. a higher value in summer and a lower value in winter.

\section{c. Trophic-based patterns at the community level}


528 The mean trophic levels of the species represented in the coupled model ROMS-

$529 \quad \mathrm{~N}_{2} \mathrm{P}_{2} \mathrm{Z}_{2} \mathrm{D}_{2}$-OSMOSE are similar with those provided by a previous application of Ecopath model to

530 the same region and period (Shannon et al. 2003, Figure 9a). Euphausiids show a higher TL in

531 the coupled model than in Ecopath (3.3 versus 2.7), but associated with a large standard

532 deviation which reflects the high variability of TL among euphausiid individuals, ranging from 2 to

533 3.9. Among the fish species, sardine shows the lowest TL (mean value of 3.13), followed by a

534 homogeneous group constituted of redeye (3.52), lanternfish (3.53), lightfish (3.53) and anchovy

535 (3.53), which have also similar TLs in Ecopath. In both models, horse mackerel displays a mean

536 trophic level a little higher than the forage fish, and the four top predator species show similar

537 values of TL: 4.5 in Ecopath for deep water hake, silver kob and snoek (respectively 4.48, 4.49,

538 and 4.59 in the coupled model) and 4.6 in Ecopath for shallow water hake versus 4.53 in the 539 coupled model.

540 As the TL can be tracked for each individual in ROMS- $\mathrm{N}_{2} \mathrm{P}_{2} \mathrm{Z}_{2} \mathrm{D}_{2}$-OSMOSE, we can draw 541 the biomass distribution of the population across TL values (Figure 9b). Three groups emerge 542 from the comparison between species. The first one concerns fish species with a mean TL 543 around 3.5, which distribution displays a single narrow peak. This is the case of redeye, 544 lanternfish, lightfish, anchovy and horse mackerel, which all appear to be specialist feeders. The 545 second group concerns the top predators (both species of Cape hake, silver kob and snoek) with 546 a mean TL around 4.5 and which appear to be largely omnivorous. The distribution of their TL is 547 much broader, reflecting their opportunism and the diversity of their prey. Finally the last group 548 concerns sardine and euphausiids, which exhibit a TL distribution with two distinct modes, 549 reflecting the change of feeding behavior between juveniles and adults. We can note that the first 550 mode of euphausiids is centered on 2.6, which is very close to the TL attributed to this group by 551 the Ecopath model (Figure 9a), but corresponds to juvenile euphausiids only in the coupled 552 ROMS- $\mathrm{N}_{2} \mathrm{P}_{2} \mathrm{Z}_{2} \mathrm{D}_{2}$-OSMOSE model.

\section{d. Food web indicators}


From the individuals' size-based interactions, the coupled model produces a posteriori an emerging food web, the structure of which can be represented and analysed in order to better understand its functioning. As the HTL model is individual-based, we can aggregate schools per size-class, per species or per functional position. To represent the food web of the southern Benguela ecosystem, we use here a classical representation with trophic links between species compartments and excluding larvae and small juveniles for diet description (only the individuals older than 6 months for fish, older than 2 months for euphausiids are considered). As predation is opportunistic in the model, a lot of interactions exist between the species. We chose to represent only the major and medium trophic links, i.e. links between a predator and its prey accounting for at least $10 \%$ of its diet in biomass as major links and between $1 \%$ and $10 \%$ of its diet as medium links (Figure 10).

In this diagram of the modeled food web, the number of species or compartments is small $(S=15)$ but the number of trophic links is large $(L=83$, including weak links $<1 \%$ of the diet), leading to a quite high linkage density $(\mathrm{L} / \mathrm{S}=5.53)$. From this diagram, it appears that copepods and euphausiids are preyed upon by numerous predators of the system, they are both linked to 9 predator species. However, their roles differ as copepods are a major prey of 7 species out of 9 , whereas euphausiids are a major prey of only horse mackerel and a medium prey of the other 8 predators. This characterizes euphausiids as generic prey, i.e. they are not fed upon massively by few predators, but they are a small part of the diet of many predators. This diagram also shows that the two species of hake, snoek and silver kob are largely opportunistic predators, feeding on 9 prey species (8 for snoek). When viewed in more detail, it appears that both species of hake have few major prey species ( 3 and 4 major links towards prey) and a lot of prey of medium importance. Conversely, silver kob and snoek have many important prey (6 for both species), and only few prey of second choice. This indicates a more balanced diet for these predators with probably no dominant prey but rather a set of prey species of equal importance. 
582 Finally, it is worth noting that sardine and horse mackerel have a middle position in the food web,

583 with the same numbers of links as both predator and as prey (4 links in each case).

584

585

586

\section{Discussion}

\section{Lessons from the calibration of the model}

The additional larval mortality rates estimated by the evolutionary algorithm can be very small, as is the case for euphausiids and mesopelagic fish. Low mortality rates do not mean that the total natural mortality is small, but alternatively may reflect the fact that most of the mortality is simulated explicitly in the model. As predation is the main process involving explicit mortality, such values can illustrate the role of euphausiids and mesopelagic fish as major prey of the modelled species community. The width of the parameter distributions provided by the genetic algorithm informs us about the importance of each parameter on the simulated species biomasses. The narrower a distribution is, the more the parameter influences the fitness (see Fig. 5). Using such information, it appears for example that sardine mortality does not strongly affect the model output, whereas snoek and other predator species such as shallow water hake and silver kob seem to have a strong impact on the overall dynamics of the system.

The estimates of availability coefficients of plankton are quite low (see Table 4), the highest being the copepods coefficient (making only $11.3 \%$ of the biomass available for HTL organisms). However, these parameters account for a lot of processes such as vertical and horizontal mismatch between plankton and predator due to differences in habitat, turbulence, avoidance of predators, diel migration, but also sinking to sea floor, all of these processes being difficult to quantify. As a comparison, Shannon and Field (1985) propose that $12 \%$ of the primary production is available to fish, which is of the same order of magnitude as the availability coefficient calibrated here. The low availability of plankton to fish may explain why the fish production observed is smaller than theoretically expected when looking at the high levels of 
610 primary production in this upwelling ecosystem (Carr 2002). We note that the value of these 611 parameters will constrain the importance of the feedback from OSMOSE down to ROMS$612 \quad \mathrm{~N}_{2} \mathrm{P}_{2} \mathrm{Z}_{2} \mathrm{D}_{2}$. Low availability of plankton will act as a filter that will dampen the top down effects

613 from the upper trophic levels to the planktonic levels. An additional outcome of the calibration is 614 the provision of estimates of mortality rates due to predation exerted by the species explicit in the 615 OSMOSE model. For example, the predation mortality rates of anchovy recruits $\left(0.72\right.$ year $\left.{ }^{-1}\right)$ and 616 sardine recruits $\left(1.52\right.$ year $\left.^{-1}\right)$ are much higher than the other sources of natural mortality $(0.4$ and

6170.36 year $^{-1}$, respectively), suggesting that most predation pressure on these two small pelagic 618 species is accounted for by species represented explicitly in the model.

\section{Lessons from the POM approach}

Overall, the coupled model ROMS- $\mathrm{N}_{2} \mathrm{P}_{2} \mathrm{Z}_{2} \mathrm{D}_{2}$-OSMOSE represents the observed diets of major fish of the Benguela ecosystem relatively well. Most of the simulated diets are quantitatively realistic and when they are not, they are qualitatively sensible, either in the order of prey importance or in the trends between areas or size classes. For all simulated diets compared with data, the differences can be attributed to one of the following causes: i) too small a contribution of euphausiids, ii) too small a contribution of demersal compared to epi-pelagic species or iii) differences in the sampling effort between data and model.

The small proportion of euphausiids in the simulated diets may be due to the great uncertainty in the estimation of euphausiid biomass in the whole area. As abundance data are not easily available for such small organisms, we used the reference biomass provided by the Ecopath model of Shannon et al. (2003) which was almost three times higher than estimated by Pillar et al. (1992). Data from Pillar et al. (1992) concern only Euphausia lucens, which is certainly a dominant species, but other important euphausiid species occur in the area (e.g. Nyctiphanes capensis on the South coast or oceanic species such as Euphausia recurva, Thysanoessa gregaria and Nematoscelis megalops). As we aim to represent the euphausiid group, the biomass 
estimate of $E$. lucens is definitely smaller than the total biomass of euphausiids. Furthermore Pillar et al. (1992) remarked that biases are associated with sampling gears, notably mesh size (estimates concern only the $>1600 \mu \mathrm{m}$ size fraction, i.e. the larger members of the population) and avoidance of the sampler by euphausiids. Conversely, biomass estimates from Shannon et al. (2003) are supposed to represent the whole macro-zooplankton group (mainly composed of euphausiids), but they come from model tuning and are not strictly based on data. Therefore the small proportion of euphausiids in simulated fish diets might be due to the uncertainty related to the euphausiid reference biomass, and probably results in its underestimation.

The second cause of difference between simulated diets and observed data may be due to overestimation of the possible interaction between epi-pelagic prey and demersal predators in the HTL model because of the absence of vertical structure. This may particularly explain the over-representation of small pelagic fish, i.e. epi-pelagic species, in the diet of hake which are demersal species, thus living near the bottom during the day, but feeding in the water column at night (L. Hutchings, pers. com.). The predation of hake by hake (either cannibalism or predation of deep-water hake by shallow water hake) observed largely in the data occurs between 150 and $400 \mathrm{~m}$ depths (Punt et al. 1992) where small pelagic fish are not abundant. It is possible that in nature hake predators spend more time surrounded by hake prey than by small pelagic prey, which is not modeled here and thus induces biases in the modeled diets.

Finally, the sampling effort might bias the direct comparison. In the coupled model, millions of stomachs per species are used to calculate diets. Conversely, sampling the marine environment allows us to access only a tiny fraction of it, in a small spatio-temporal window. It is recognized that a minimum sampling effort is required to describe patterns correctly, estimated by McQueen and Griffiths (2004) to be 75-80 full stomachs per sampling event for describing the proportion in biomass of primary prey. These authors also highlight the frequency of the sampling required to correctly represent an average diet; ideally sampling once a week for consideration of seasonal variability would result in 3890 stomachs with food required for precisely describing 
annual diet. Furthermore, surveys conducted in a too coarse spatio-temporal grid may also risk incorrect descriptions of diets when diets are highly heterogeneous in time and space due to the opportunistic feeding of predators. In such cases, observed diets should be used with caution when comparing with model outputs (Punt et al. 1992).

At the population level, the seasonal variation of mean anchovy size is well simulated by the model. Even if a strong interannual variability is observed in landings data, we can consider that the model represents the dynamics of population size structure quite well. The fit between model output and data is not so good when looking at the absolute values, as the overall mean size is smaller in the model than in the data. However, Fairweather et al. (2006) note that the mean size they observed is probably over-estimated because fishermen discard the smallest fish, a behavior not represented in the model. Fishermen may also avoid catching small fish (L. Hutchings, pers. com.).

At the upper hierarchical level, the model also provides consistent output concerning species TL, thus synthesizing well the trophic position of each species and by extension, the global trophic functioning of the system. Apart from euphausiids, the ordination of species according to their TL is similar between the coupled model and Ecopath (see Fig. 9). The particular case of euphausiids illustrates the importance of the selection of individuals included in the TL calculation. Here, by only considering larger individuals (as it is classically the case for fish species), the mean TL of this population is higher than the TL given to macro-zooplankton in Ecopath. The TL distribution moderates this difference as it clearly indicates that part of the euphausiid population has a trophic level lower than 3. Finally, the high mean trophic level of euphausiids can be explained by the TL of copepods and fish eggs, set to 2.5 and 3 relatively, which constitute a significant part of euphausiids diet (See Table 4).

Following the POM approach advocated by Grimm et al. (2005), the coupled model ROMS- $\mathrm{N}_{2} \mathrm{P}_{2} \mathrm{Z}_{2} \mathrm{D}_{2}$-OSMOSE allowed us to reproduce independent patterns observed in the 
694

southern Benguela at different levels, therefore validating different aspects of the model, part of its structural assumptions and parameterization.

\section{Opportunistic trophic interactions}

Predation is a key process in the coupled model, being represented both in the plankton model and the HTL model as well as serving as the coupling process between OSMOSE and ROMS- $N_{2} P_{2} Z_{2} D_{2}$. Due to the opportunistic representation of predation, the trophic structure of the southern Benguela emerges from local interactions and is not set a priori. The emerging food web is complex and involves several links between the components, as indicated by the high linkage density (see Fig. 10). The food web drawn from the present study has very few compartments, aggregated on a taxonomic basis as it is often the case in similar studies (Field et al. 1991, Shannon et al. 2003). However, information is available at a finer level in this model, and it would be possible to address different issues of food web theory by constructing alternative representations of the food web, for example considering trophic guilds, i.e. groups of organisms with identical set of predators and prey (Link 2005) regardless of the taxonomy, or partitioning species into several size classes.

Due to the extensive set of outputs available from the coupled model it is possible to quantify the trophic links by means of different indicators, and thus better understand the global trophic functioning of this ecosystem. It appears that species situated at the same position of the food web (basal, intermediate or apex) can display different patterns of linkage with other components. In our application, both species of hake appear to be more specialist than silver kob and snoek, by having a smaller proportion of strong links. The existence of strong links could be wrongly interpreted as preference for specific prey, either in model output or in observed data. It is worth recalling that predation is opportunistic in the present model, thus true specialists are not modeled. Gerking (1994) remarks that true specialists are difficult to identify in the pelagic environment, as feeding on a very small number of prey may simply illustrate the dominance of 
722 these prey in the predator's habitat. In the coupled model, the apparent specialization of hakes

723 may reflect a spatio-temporal mismatch between the predators and other prey species, or a lack 724 of suitably sized prey at right time and place.

One asset of this coupled model is to provide TL distributions rather than a unique mean

727 TL per species. Such distributions are very informative about inter-individuals variability and 728 ontogenetic omnivory. Thanks to the modularity of the model, it is possible to compute such 729 distributions per area in order to highlight different trophic positions for one species according to 730 its environment. In the present application of the model to the southern Benguela ecosystem, we 731 can note a clear peak at TL 3.5. This pattern concerns mainly planktivorous species, and is 732 explained by the constant $T L$ set to mesozooplankton $(T L=2.5)$, this latter group representing the 733 copepods which are either herbivorous, carnivorous or omnivorous according to the species 734 considered. Because the copepod species composition changes over space and time, and so do 735 the aggregated diets of the community, the resulting TL of the copepod compartment should present some variability which is not represented here. Copepod trophic level not only propagates

737 to their predator levels (small pelagic fish, $T L=3.5$ ) but also to the top predator level (mean $T L$ 738 around 4.5). It is likely that adopting a variable TL for the meso-zooplankton group would tend to 739 increase the inter-species variability of mean TLs and also to render the intra-species TL 740 distribution more uniform for HTL species.

\section{Potential of the coupled model} effects of fishing and climate change, as well as the propagation of these effects up and down the food web. Its opportunistic predation process is a necessary condition for investigating the spatio-

747 temporal variability of the trophic structure and functioning of marine ecosystems, especially in a 748 changing environment. The individual-based structure of the HTL model allows to track 749 information at different hierarchical levels - individuals, cohorts, population or community- and at 
different spatio-temporal scales. This possibility was presented here for the trophic levels, either averaged for each species or used at the individual level to represent the TL distributions. This modularity applies to other community and population indicators such as fish size, biomass, etc.

In the model configuration presented here, the mechanisms of fish distribution are not explicitly represented but the fish spatial dynamics are forced by horizontal distribution maps that are based on surveys and are provided in input to the model. This approach is appropriate for the purpose of the present study that analyses the behaviour of the ecosystem in an average year. But for exploring the effects of climate change on the southern Benguela ecosystem, the model would need to explicit the link between fish spatial distribution and some key climate variables. Current developments are being undertaken to model climate niches for the species included in OSMOSE (Yemane et al. in prep) so that climate change explicitly drives fish spatial distributions. One can also note that in the present application of the HTL model, no vertical dimension is implemented, and it appeared to induce some biases in some output such as diets. Knowing this limit, there have been recent developments in the OSMOSE model, allowing one to account for the vertical distribution in an implicit way, by introducing a matrix of accessibility in the water column between predators and their prey.

The HTL model OSMOSE has been used for testing various fisheries management scenarios including marine protected areas (Shin and Cury 2001b, Yemane et al. 2009), changes in fishing pressure and moratoriums (Shin et al. 2004, Vergnon et al. 2008, Marzloff et al. 2009, Travers et al. 2010, Smith et al. 2011) and for studying the sensitivity and behavior of ecosystem indicators (Travers et al. 2006). Its coupling with the ROMS- $N_{2} P_{2} Z_{2} D_{2}$ model opens interesting perspectives for analyzing and better understanding the propagation of combined effects of climate and fishing perturbations up and down the food web (Fu et al. 2012, Fu et al. 2013, Travers et al. 2009).

\section{Acknowledgments}


780 Commission (contract FP6-511106). Morgane Travers-Trolet was supported by a EUR-OCEANS

781 scholarship. Yunne-Jai Shin was partly funded by the French project EMIBIOS (FRB, contract no.

782 APP-SCEN-2010-II) and the European collaborative project MEECE (FP7, contract no. 212085).

783

784 


\section{References}

Andrews W.R.H., Hutchings L. 1980. Upwelling in the Southern Benguela Current. Progress in Oceanography 9: 1-8.

Araújo J.N, Mackinson S., Stanford R.J., Sims D.W., Southward A.J., Hawkins S.J., Ellis J.R., Hart P.J.B. 2006. Modelling food web interactions, variation in plankton production, and fisheries in the western English Channel ecosystem. Marine Ecology Progress Series 309: 175-187.

Bahamón N., Cruzado A. 2003. Modelling nitrogen fluxes in oligotrophic environments: NW Mediterranean and NE Atlantic. Ecological Modelling 163: 223-244.

Barange M., Pillar S. C., Hampton I. 1998. Distribution patterns, stock size and life-history strategies of Cape horse mackerel Trachurus trachurus capensis, based on bottom trawl and acoustic surveys. In Benguela Dynamics:Impacts of Variability on Shelf-Sea Environments and their Living Resources. Pillar S. C., Moloney C. L., Payne A. I. L. and F. A. Shillington (Eds). South African Journal of Marine Science 19: 433-448.

Bax N.J. 1998. The significance and prediction of predation in marine fisheries. ICES Journal of Marine Science 55: 997-1030.

Carr M.-E. 2002. Estimation of potential productivity in Eastern Boundary Currents using remote sensing. Deep Sea Research Part II 49: 59-80.

Chifflet M., Andersen V., Prieur L., Dekeyser I. 2001. One-dimensional model of short-term dynamics of the pelagic ecosystem in the NW Mediterranean Sea: Effects of wind events. Journal of Marine Systems 30: 89-114.

Conkright M. E., Levitus S., Boyer T. P. 1994. World Ocean Atlas 1994, vol. 1, Nutrients, NOAA Atlas NESDIS 1, 162 pp., Natl. Oceanic and Atmos. Admin., Silver Spring, Md.

Cury P. M., Shin Y.-J., Planque B., Durant J. M., Fromentin J.-M., Kramer-Schadt S., Stenseth N. C., Travers M., Grimm V. 2008. Ecosystem Oceanography for global change in fisheries. Trends in Ecology \& Evolution 23: 338-346. 
Da Silva A.M., Young C.C., Levitus S. 1994. Atlas of Surface Marine Data 1994, vol. 1, Algorithms and Procedures, NOAA Atlas NESDIS 6, Natl. Oceanic and Atmos. Admin., Silver Spring, Md., 74 pp.

Dow D.D., O’Reilly J.E., Green J.R. 2006. Microzooplankton. In: Link, J.S., Griswold, C.A., Methratta, E.T., Gunnard, J., (eds), Documentation for the Energy Modeling and Analysis eXercise (EMAX). US Dep. Commer., Northeast Fisheries Science Center 06-15; pp. 21-25.

Duboz R., Shin Y.-J., Travers M., Versmisse D. 2010. Application of an evolutionary algorithm to the inverse parameter estimation of an individual-based model. Ecological Modelling 221: 840-849.

Fairweather T.P., van der Lingen C.D., Booth A.J., Drapeau L., van der Westhuizen J.J. 2006. Indicators of suistainable fishing for South African sardine Sardinops sagax and anchovy Engraulis encrasicolus. South African Journal of Marine Science 28: 661-680.

FAO 2003 Implementation of ecosystem approach to fisheries management to achieve responsible fisheries and to restore fisheries resources and marine environments, FAO Commitee on Fisheries, Rome.

Fasham M., Ducklow H., McKelvie S. 1990. A nitrogen-based model of plankton dynamics in the oceanic mixed layer. Journal of Marine Research 48: 591-639.

Field J.G., Crawford R.J.M., Wickens P.A., Moloney C.L., Cochrane K.L., Villacastic-Herraro C.A. 1991. Network Analysis of Benguela Pelagic Food Webs, Benguela Ecology Programme, Workshop on Seal-Fishery Biological Interactions. University of Cape Town, BEP/SW91/M5a

Field J.C., Francis R.C., Aydin K. 2006. Top-down modeling and bottom-up dynamics: Linking a fisheries-based ecosystem model with climate hypotheses in the Northern California Current. Progress in Oceanography 68: 238-270.

Fu C., Shin Y.J., Perry R.I, King J., Liu H. 2012. Exploring Climate and Fishing Impacts in an Ecosystem Model of the Strait of Georgia, British Columbia. In: G.H. Kruse, H.I. Browman, K.L. Cochrane, D. Evans, G.S. Jamieson, P.A. Livingston, D. Woodby, and C.I. Zhang (eds.), 
Global Progress in Ecosystem-Based Fisheries Management. Alaska Sea Grant, University of Alaska Fairbanks, Fairbanks.

Fu C., Perry I., Shin Y.-J., Schweigert J., Liu H. 2013. An ecosystem modelling framework for incorporating climate regime shifts into fisheries management. Progress in Oceanography, in press.

Fulton E.A. 2010. Approaches ot end-to-end ecosystem models. Journal of Marine Systems 81: 171-183.

Gerking S.D. 1994. Feeding Ecology of Fish. Academic Press, California, 416pp.

Griffiths M.H. 2002. Life history of South African snoek, Thyrsites atun (Pisces: Gempylidae): a pelagic predator of the Benguela ecosystem. Fishery Bulletin 100: 690-710.

Grimm V., Revilla E., Berger U., Jeltsch F., Mooij W.M., Railsback S.F., Thulke H.-H., Weiner J., Wiegand T., DeAngelis D.L. 2005. Pattern-oriented modeling of agent-based complex systems: lessons from ecology. Science 310: 987-991.

Hsieh C.H., Reiss C.S., Hewitt R.P., Sugihara G. 2008. Spatial analysis shows that fishing enhances the climatic sensitivity of marine fishes. Canadian Journal of Fisheries and Aquatic Sciences 65: 947-961.

James A.G. 1987. Feeding Ecology, diet and field-based studies on feeding selectivity of the Cape anchovy Engraulis capensis Gilchrist. In: Payne, A.I.L., Gulland, J.A., Brink, K.H. (eds), The Benguela and comparable ecosystems. South African Journal of Marine Science 5: 673692.

Jennings S., Pinnegar J.K., Polunin N.V.C., Boon T.W. 2001. Weak cross-species relationships between body size and trophic level belie powerful size-based trophic structuring in fish communities. Journal of Animal Ecology 70: 934-944.

Koné V., Machu E., Penven P., Andersen V., Garçon V., Demarcq H., Fréon P. 2005. Modelling the primary and secondary productions of the Southern Benguela upwelling system: a comparative study through two biogeochemical models. Global Biogeochemical Cycles 19: GB4021. 
Lacroix G., Nival P. 1998. Influence of meteorological variability on primary production dynamics in the Ligurian Sea (NW Mediterranean Sea) with a 1D hydrodynamic/biological model. Journal of Marine Systems 16: 23-50.

Lindenmayer D.B., Likens G.E., Krebs C.J., Hobbs R.J. 2010. Improved probability of detection of ecological "surprises". Proceedings of the National Academy of Sciences 107(51): 2195721962.

Link J.S., Stockhausen W.T., Methratta E.T. 2005. Food-web theory in marine ecosystems. In: Belgrano, A., Scharler, U.M., Dunne, J., Ulanowicz, R.E. (eds), Aquatic food webs an ecosystem approach, pp 98-113.

Link J.S., Yemane D., Shannon L.J., Coll M., Shin Y.-J., Hill L., and Borges M.F. 2010. Relating marine ecosystem indicators to fishing and environmental drivers: an elucidation of contrasting responses. ICES Journal of Marine Science 67: 787-795.

Logan J., Haas H., Deegan L., Gaines E. 2006. Turnover rates of nitrogen stable isotopes in the salt marsh mummichog, Fundulus heteroclitus, following a laboratory diet switch. Oecologia 147: 391-395.

Marzloff M., Shin Y.-J., Tam J., Travers M., Bertrand A. 2009. Trophic structure of the Peruvian marine ecosystem in 2000-2006: Insights on the effects of management scenarios for the hake fishery using the IBM trophic model Osmose. Journal of Marine Systems 75(1-2): 290304.

McQueen N., Griffiths M.H. 2004. Influence of sample size and sampling frequency on the quantitative dietary descriptions of a predatory fish in the Benguela ecosystem. In: Shannon, L.J., Cochrane, K.L., Pillar, S.C. (eds), Ecosystem approaches to fisheries in the Southern Benguela. African Journal of Marine Science 26: 205-217.

Ménard F., Labrune C., Shin Y.-J., Asine A.S., Bard F.X. 2006. Opportunistic predation in tuna: a size-based approach. Marine Ecology Progress Series 323: 223-231.

Moloney C., Field J. 1991. The size-based dynamics of plankton food webs. I. A simulation model of carbon and nitrogen flows. Journal of Plankton Research 13: 1003-1038. 
Olivieri R. A., Chavez F. P. 2000. A model of plankton dynamics for the coastal upwelling system of Monterey Bay, California. Deep Sea Research Part // 47: 1077-1106.

Oschlies A., Garçon V. 1999. An eddy-permitting coupled physicalbiological model of the North Atlantic: 1. Sensitivity to advection numerics and mixed layer physics. Global Biogeochemical Cycles 13(1): 135-160.

Payne A. I. L., Rose B., and Leslie R. W. 1987. Feeding of hake and a first attempt at determining their trophic role in the South African west coast marine environment. In The Benguela and Comparable Ecosystems. Ed. by A. I. L. Payne, J. A. Gulland and K. H. Brink. South African Journal of Marine Science 5: 471-501.

Penven P., Roy C., Brundrit G., Colin de Verdière A., Fréon P., Johnson A., Lutjeharms J., Shillington F. 2001. A regional hydrodynamic model of upwelling in the Southern Benguela. South African Journal of Science 97: 472-475.

Pillar S.C. 1987. Distribution and population dynamics of Euphausia Lucens (Euphausiacea) in the southern Benguela current. PhD Thesis, University of Cape Town.

Pillar S. C., and Barange M. 1993. Feeding selectivity of juvenile Cape hake Merluccius capensis in the southern Benguela. South African Journal of Marine Science 13: 255-268.

Pillar S. C., and Barange M. 1995. Diel feeding periodicity, daily ration and vertical migration of juvenile Cape hake off the west coast of South Africa. Journal of Fish Biology 47: 753-768.

Pillar S. C., and Barange M. 1997. Diel variability in bottom trawl catches and feeding activity of the Cape hakes off the west coast of South Africa. ICES Journal of Marine Science 54: 485499.

Pillar S.C., Stuart V., Barange M., Gibbons M.J. 1992. Community structure and trophic ecology of Euphausiids in the Benguela ecosystem. In: Payne, A.I.L., Brink, K.H., Mann, K.H., Hilborn, R. (eds), Benguela Trophic Funtioning, South African Journal of Marine Science 12: 393-409.

Pillar S. C., and Wilkinson I. S. 1995. The diet of Cape hake Merluccius capensis on the south coast of South Africa. South African Journal of Marine Science 15: 225-239. 
Pine W.E., Martell S.J.D., Walters C., Kitchell J.F. 2009. Counterintuitive Responses of Fish Populations to Management Actions: Some Common Causes and Implications for Predictions Based on Ecosystem Modeling. Fisheries 34(4): 165-180.

Popova E. E., Lozano C. J., Srokosz M. A., Fasham M. J. R., Haley P. J., Robinson A. R. 2002. Coupled 3D physical and biological modelling of the mesoscale variability observed in northeast Atlantic in spring 1997: Biological processes. Deep Sea Research Part I 49: 1741-1768.

Probyn T.A. 1992. The inorganic nitrogen nutrition of phytoplankton in the southern Benguela: new production, phytoplankton size and implications for pelagic food webs. In: Payne, A.I.L., Brink, K.H., Mann, K.H., Hilborn, R. (eds), Benguela Trophic Funtioning, South African Journal of Marine Science 12: 411-420.

Punt A.E., Leslie R.W., du Plessis S.E. 1992. Estimation of the annual consumption of food by Cape hake Merluccius capensis and M. Paradoxus off the South African West Coast. In: Payne, A.I.L., Brink, K.H., Mann, K.H., Hilborn, R. (eds), Benguela Trophic Functioning. South African Journal of Marine Science 12: 611-634.

Rose K.A., Allen J.I., Artioli Y., Barange M., Blackford J., Carlotti F., Cropp R., Daewel U., Edwards K., Flynn K., Hill S., HilleRisLambers R., Huse G., Mackinson S., Megrey B., Moll A., Rivkin R., Salihoglu B., Schrum C., Shannon L.J., Shin Y.-J., Smith S.L., Smith C., Solidoro C., St John M., Zhou M. 2010. End-to-end models for the analysis of marine ecosystems: challenges, issues, and next steps. Marine and Coastal Fisheries: Dynamics, Management, and Ecosystem Science 2(1): 115-130.

Scharf F.S., Juanes F., Rountree R.A. 2000. Predator size-prey size relationships of marine fish predators: interspecific variation and effects of ontogeny and body size on trophic niche breadth. Marine Ecology Progress Series 208: 229-248.

Shannon L. V., Field J. G., 1985. Are fish stocks food-limited in the southern Benguela pelagic ecosystem? Marine Ecology Progress Series 22: 7-19.

Shannon L., Moloney C., Jarre A., Field J. 2003. Trophic flows in the southern Benguela during the 1980s and 1990s. Journal of Marine Systems 39: 83-116. 
Shchepetkin A., McWilliams J.C. 2005. Regional Ocean Modeling System: a split-explicit ocean model with free-surface and topography following vertical coordinate. Ocean Modelling 9: 347-404.

Shin Y., Cury P. 2001a. Exploring fish community dynamics through size-dependent trophic interactions using a spatialized individual-based model. Aquatic Living Resources 14: 65-80.

Shin Y.-J., P. Cury 2001b - Simulation of the effects of Marine Protected Areas on yield and diversity using a multispecies, spatially explicit, individual-based model. In: Kruse, G. H.; Bez, N.; Booth, A.; Dorn, M. W.; Hills, S.; Lipcius, R. N.; Pelletier, D.; Roy, C.; Smith, S. J., and Witherell, D., (eds.). Spatial processes and management of marine populations. University of Alaska Sea Grant ed. Fairbanks; 2001; pp. 627-642.

Shin Y., Cury P. 2004. Using an individual-based model of fish assemblages to study the response of size spectra to changes in fishing. Canadian Journal of Fisheries and Aquatic Sciences 61: 414-431.

Shin Y., Shannon L.J., Cury P.M. 2004. Simulations of fishing effects on the Southern Benguela fish community using the individual-based model OSMOSE. Lessons from a comparison with Ecosim simulations. In: Shannon, L.J., Cochrane, K.L., Pillar, S.C. (eds), Ecosystem approaches to fisheries in the Southern Benguela. African Journal of Marine Science 26: 95114.

Shin Y.-J., Travers M., Maury O. 2010. Coupling models low and high trophic levels models: towards a pathways-orientated approach for end-to-end models. Progress in Oceanography 84: 105-112.

Smith M.D., Fulton E.A., Day R.W., Shannon L.J., Shin Y.-J. submitted. Ecosystem modelling in the southern Benguela: comparisons of Atlantis, Ecopath with Ecosim, and OSMOSE under fishing scenarios. Journal of Marine Systems.

Tian R. C., Vézina A., Legendre L., Ingram R.G., Klein B., Packard T., Roy S., Savenkoff C., Silverberg N., Therriault J.C., Tremblay J.E. 2000. Effects of pelagic food-web interactions and nutrient remineralization on the biogeochemical cycling of carbon: A modeling approach. Deep Sea Research Part II 47: 637-662. 
974 Travers M., Shin Y.J., Shannon L. and Cury P. 2006. Simulating and testing the sensitivity of ecosystem-based indicators to fishing in the southern Benguela ecosystem. Canadian Journal of Fisheries and Aquatic Sciences 63: 943-956.

Travers M., Shin Y.-J., Jennings S., Cury P. 2007. Towards end-to-end models for investigating trophic controls and large changes induced by climate and fishing in marine ecosystems. Progress in Oceanography 75: 751-770.

Travers M., Shin Y.-J., Jennings S., Machu E., Huggett J.A., Field J., Cury P. 2009. Two-way coupling versus one-way forcing of plankton and fish models to predict ecosystem changes in the Benguela. Ecological Modelling 220: 3089-3099.

Travers M., Watermeyer K., Shannon L.J., Shin Y.-J. 2010. Changes in food web structure under scenarios of overfishing in the southern Benguela: comparison of the Ecosim and OSMOSE modelling approaches. Journal of Marine Systems 79(1-2): 101-111.

Travers-Trolet M., Shin Y.-J., Shannon L., Moloney C., Field J. (in prep) Combination of fishing and climate forcing in the southern Benguela upwelling ecosystem: an end-to-end modelling approach reveals dampened effects.

Trueman C.N., McGill R.A.R., Guyard P.H. 2005. The effect of growth rate on tissue-diet isotopic spacing in rapidly growing animals. An experimental study with Atlantic salmon (Salmo salar). Rapid Communications in Mass Spectrometry 19: 3239-3247.

van der Lingen C.D. 1998. Gastric evacuation, feeding periodicity and daily ration of sardine Sardinops sagax in the southern Benguela upwelling ecosystem. In: Pillar, S.C., Moloney, C.L., Payne, A.I.L., Shillington, F.A. (eds), Benguela Dynamics. South African Journal of Marine Science 19: 305-316.

van der Lingen C.D. 2002. Diet of sardine Sardinops sagax in the southern Benguela upwelling ecosystem. South African Journal of marine Science 24: 301-316.

Vergnon R., Shin Y.-J., Cury P. 2008. Cultivation, Allee effect and resilience of large demersal fish populations. Aquatic Living Resources 21: 287-295. 
1000 Vermisse D. 2008. Gestion de la complexité formelle et opérationnelle des systèmes complexes:

1001 Application aux anthroposystèmes marins. Ph.D. Thesis, Université du Littoral Côte d'Opale,

1002 Calais, France, 207 pp.

1003 Walters C., Christensen V., Pauly D. 1997. Structuring dynamic models of exploited ecosystems

1004 from trophic mass-balance assessments. Reviews in Fish Biology and Fisheries 7: 139-172.

1005 Yemane D., Shin Y.-J., Field J. 2009. Exploring the effect of marine protected areas on the

1006 dynamics of fish communities in the southern Benguela: an Individual Based Modelling

$1007 \quad$ approach. ICES Journal of marine Science 66: 378-387.

1008 Yemane D., Coetzee J., van der Lingen C., Twatwa N. (in prep) Modeling the distribution of small

1009 pelagic fish in the southern Benguela using remotely sensed variables

1010 


\section{$\underline{\text { Tables }}$}

Table 1: Parameter values of the biogeochemical model $\mathrm{N}_{2} \mathrm{P}_{2} \mathrm{Z}_{2} \mathrm{D}_{2}$ (from Koné et al. 2005)

\begin{tabular}{|c|c|c|c|c|}
\hline Parameter & Description & Value & Unit & Reference \\
\hline \multicolumn{5}{|c|}{ Phytoplankton groups } \\
\hline$\alpha$ & $\begin{array}{l}\text { Initial slope of the } \\
\text { phytoplankton-irradiance curve }\end{array}$ & $\begin{array}{ll}\text { Flagellates: } & 0.025 \\
\text { Diatoms: } & 0.04\end{array}$ & $\mathrm{mg} \mathrm{C}\left(\mathrm{mg} \text { Chla W } \mathrm{m}^{-2} \mathrm{~d}\right)^{-1}$ & $\begin{array}{l}\text { Oschlies and Garçon (1999) } \\
\text { Popova et al. (2002) }\end{array}$ \\
\hline$a$ & Maximal growth rate at $0^{\circ} \mathrm{C}$ & $\begin{array}{ll}\text { Flagellates: } & 0.557 \\
\text { Diatoms: } & 0.8356 \\
\end{array}$ & $d^{-1}$ & Koné et al. (2005) \\
\hline$b$ & & 1.066 & n.d. & $\begin{array}{l}\text { Oschlies and Garçon (1999) } \\
\text { Popova et al. (2002) }\end{array}$ \\
\hline$K_{\mathrm{NO} 3}$ & $\begin{array}{l}\text { Half-saturation constant for } \\
\mathrm{NO}_{3} \text { uptake }\end{array}$ & $\begin{array}{ll}\text { Flagellates: } & 1.0 \\
\text { Diatoms: } & 2.0 \\
\end{array}$ & $\mathrm{mmol} \mathrm{N} \cdot \mathrm{m}^{-3}$ & Chifflet et al. (2001) \\
\hline$K_{N H 4}$ & $\begin{array}{l}\text { Half-saturation constant for } \\
\mathrm{NH}_{4} \text { uptake }\end{array}$ & $\begin{array}{ll}\text { Flagellates: } & 0.5 \\
\text { Diatoms: } & 0.7 \\
\end{array}$ & $\mathrm{mmol} \mathrm{N} \cdot \mathrm{m}^{-3}$ & $\begin{array}{l}\text { Tian et al. (2000) Olivieri and Chavez (2000) } \\
\text { Bahamón and Cruzado (2003) Lacroix and Nival (1998) }\end{array}$ \\
\hline$m_{p}$ & Mortality rate & $\begin{array}{ll}\text { Flagellates: } & 0.027 \\
\text { Diatoms: } & 0.03\end{array}$ & $d^{-1}$ & $\begin{array}{l}\text { Koné et al. (2005) } \\
\text { Lacroix and Nival (1998) Oschlies and Garçon (1999) }\end{array}$ \\
\hline \multicolumn{5}{|c|}{ Zooplankton groups } \\
\hline$K_{z}$ & $\begin{array}{l}\text { Half-saturation rate constant } \\
\text { for ingestion }\end{array}$ & $\begin{array}{ll}\text { Ciliates: } & 1.0 \\
\text { Copepods: } & 2.0 \\
\end{array}$ & $\mathrm{mmol} \mathrm{N} \cdot \mathrm{m}^{-3}$ & Koné et al. (2005) \\
\hline $\operatorname{gmax}$ & Growth rate & $\begin{array}{ll}\text { Ciliates: } & 1.2 \\
\text { Copepods: } & 0.96 \\
\end{array}$ & $d^{-1}$ & $\begin{array}{l}\text { Chifflet et al. (2001) Bahamón and Cruzado (2003) } \\
\text { Lacroix and Nival (1998) }\end{array}$ \\
\hline$e_{1}$ & Capture efficiency for ciliates & $\begin{array}{ll}\text { Flagellates: } 1.0 \\
\text { Diatoms: } & 0.4 \\
\end{array}$ & n.d. & $\begin{array}{l}\text { Chifflet et al. (2001) } \\
\text { Koné et al. (2005) }\end{array}$ \\
\hline$e_{2}$ & $\begin{array}{l}\text { Capture efficiency for } \\
\text { copepods }\end{array}$ & $\begin{array}{ll}\text { Flagellates: } & 0.5 \\
\text { Diatoms: } & 1.0 \\
\text { Ciliates: } & 0.4 \\
\end{array}$ & n.d. & $\begin{array}{l}\text { Lacroix and Nival (1998) } \\
\text { Chifflet et al. (2001) } \\
\text { Koné et al. (2005) }\end{array}$ \\
\hline$m_{z}$ & Mortality rate & $\begin{array}{ll}\text { Ciliates: } & 0.025 \\
\text { Copepods: } & 0.05\end{array}$ & $d^{-1}$ & Koné et al. (2005) Olivieri and Chavez (2000) \\
\hline
\end{tabular}


Table 2: Feeding size ranges of HTL organisms expressed as predator/prey size ratios. When information is available a split around the size threshold may be used to separate larvae and juvenile feeding size range from adult feeding size range. Minimum and maximum ratios are threshold values for predator length over prey length ratio and correspond to the boundary of the feeding size range. Values are computed from literature (see appendix D).

\begin{tabular}{|c|c|c|c|c|c|}
\hline \multirow[b]{2}{*}{ Species } & \multirow[b]{2}{*}{$\begin{array}{l}\text { Size } \\
\text { threshold } \\
\text { (cm) }\end{array}$} & \multicolumn{2}{|c|}{$\begin{array}{l}\text { Minimum } \\
\text { predator/prey size } \\
\text { ratio }\end{array}$} & \multicolumn{2}{|c|}{$\begin{array}{l}\text { Maximum } \\
\text { predator/prey size } \\
\text { ratio }\end{array}$} \\
\hline & & $\begin{array}{l}\text { Larvae / } \\
\text { juvenile }\end{array}$ & Adult & $\begin{array}{l}\text { Larvae / } \\
\text { juvenile }\end{array}$ & Adult \\
\hline Euphausiids & 0.6 & 5 & 5 & 1000 & 500 \\
\hline Anchovy & 8 & 3.5 & 3.5 & 100 & 500 \\
\hline Sardine & 10 & 4 & 100 & 100 & 10000 \\
\hline Redeye & - & \multicolumn{2}{|c|}{4} & \multicolumn{2}{|c|}{80} \\
\hline Lanternfish & - & \multicolumn{2}{|c|}{3.5} & \multicolumn{2}{|c|}{80} \\
\hline Lightfish & - & \multicolumn{2}{|c|}{3.5} & \multicolumn{2}{|c|}{80} \\
\hline Horse mackerel & - & \multicolumn{2}{|c|}{5} & \multicolumn{2}{|c|}{100} \\
\hline Shallow water hake & 27 & 3 & 1.8 & 30 & 30 \\
\hline Deep water hake & 29 & 3 & 1.8 & 30 & 30 \\
\hline Snoek & - & \multicolumn{2}{|c|}{3} & \multicolumn{2}{|c|}{30} \\
\hline Silver kob & - & \multicolumn{2}{|c|}{3} & \multicolumn{2}{|c|}{30} \\
\hline
\end{tabular}


Table 3: Input parameters of OSMOSE for the 11 fish species modelled explicitly. $L \infty, K$, and $t_{0}$ are the parameters of the von Bertalanffy growth model; $\mathrm{c}$ is Fulton's condition factor and $\mathrm{b}$ the exponent of the Length-Weight allometric relationship; $\varphi$ is relative fecundity; $a_{\text {mat }}$ is age at maturity; $a_{\max }$ is longevity; $M_{\text {nat }}$ is an additional mortality rate (resulting from predation by other species of the ecosystem that are not explicitly modelled); $F$ is the annual fishing mortality rate; $a_{\mathrm{rec}}$ is age of recruitment; $F_{\max }$ is the maximum ration of food for predators, $\xi_{\text {crit }}$ is the critical threshold of predation efficiency below which maintenance function is not fulfilled and $M_{\xi \max }$ is the maximum starvation mortality rate. Values reported in the table come from literature (see appendix D).

\begin{tabular}{|c|c|c|c|c|c|c|c|c|c|c|c|c|c|c|}
\hline \multirow[b]{2}{*}{ Species } & \multicolumn{5}{|c|}{ Growth } & \multicolumn{3}{|c|}{ Reproduction } & \multicolumn{3}{|c|}{ Survival } & \multicolumn{3}{|c|}{ Predation } \\
\hline & $\begin{array}{l}\mathrm{L}_{\infty} \\
\mathrm{cm}\end{array}$ & $\begin{array}{l}\mathrm{K} \\
y^{-1}\end{array}$ & $\begin{array}{l}\mathrm{t}_{0} \\
y\end{array}$ & $\begin{array}{c}\mathrm{C} \\
\mathrm{g} \cdot \mathrm{cm}^{-3}\end{array}$ & $b$ & $\begin{array}{c}\varphi \\
\text { eggs. } g^{-1}\end{array}$ & $\begin{array}{c}\mathrm{a}_{\mathrm{mat}} \\
y\end{array}$ & $\begin{array}{c}a_{\max } \\
y\end{array}$ & $\begin{array}{c}M_{\text {nat }} \\
y-1\end{array}$ & $\begin{array}{c}a_{\mathrm{rec}} \\
y\end{array}$ & $\begin{array}{c}\mathrm{F} \\
y-1\end{array}$ & $\begin{array}{c}\mathrm{F}_{\max } \\
g \cdot b o d y \\
g^{-1} \cdot y^{-1}\end{array}$ & $\xi_{c r i t}$ & $\begin{array}{c}M_{\xi \max } \\
y^{-1}\end{array}$ \\
\hline Euphausiids & 1.84 & 1.682 & -0.1975 & 0.00738 & 3.16 & 42254 & 0.3 & 1 & 0.1 & - & 0 & 3.5 & 0.57 & 1 \\
\hline Anchovy & 14.8 & 1.37 & -0.03 & 0.007 & 3 & 8000 & 1 & 5 & 0.403 & 1 & 0.23 & 3.5 & 0.57 & 1 \\
\hline Sardine & 26 & 0.26 & -1.5 & 0.009 & 3 & 2400 & 2 & 10 & 0.365 & 1 & 0.16 & 3.5 & 0.57 & 1 \\
\hline Redeye & 30.1 & 0.71 & 0.28 & 0.009 & 3 & 750 & 1 & 6 & 0.208 & 1 & 0.04 & 3.5 & 0.57 & 1 \\
\hline Lanternfish & 7 & 1.66 & 0.06 & 0.008 & 3 & 646 & 0.5 & 2 & 0.226 & 1 & 0.0003 & 3.5 & 0.57 & 1 \\
\hline Lightfish & 6 & 1.15 & 0.06 & 0.008 & 3 & 334 & 0.5 & 2 & 0.226 & 1 & 0.0003 & 3.5 & 0.57 & 1 \\
\hline Horse mackerel & 54.5 & 0.183 & -0.65 & 0.009 & 3 & 250 & 3 & 8 & 0.314 & 2 & 0.06 & 3.5 & 0.57 & 1 \\
\hline Shallow water hake & 270.6 & 0.039 & -0.73 & 0.006543 & 3.0425 & 500 & 4 & 15 & 0.228 & 3 & 0.23 & 3.5 & 0.57 & 1 \\
\hline Deep water hake & 219.4 & 0.049 & -0.914 & 0.007846 & 2.9759 & 500 & 4 & 15 & 0.174 & 3 & 0.33 & 3.5 & 0.57 & 1 \\
\hline Snoek & 115.3 & 0.294 & -0.1 & 0.018 & 3 & 130 & 3 & 10 & 0.132 & 2 & 0.25 & 3.5 & 0.57 & 1 \\
\hline Silver kob & 116 & 0.12 & -1.47 & 0.007 & 3 & 150 & 2 & 25 & 0.228 & 3 & 0.181 & 3.5 & 0.57 & 1 \\
\hline
\end{tabular}


Table 4: Parameters of the plankton groups of the ROMS $-\mathrm{N}_{2} \mathrm{P}_{2} \mathrm{Z}_{2} \mathrm{D}_{2}$ model required for implementing the two-way coupling with OSMOSE

\begin{tabular}{lccccc}
\hline & $\begin{array}{c}\text { Size range } \\
(\mathrm{mm})\end{array}$ & $\begin{array}{c}\text { Initial mortality } \\
\text { rates }\left(\mathrm{d}^{-1}\right)\end{array}$ & $\begin{array}{c}\text { Trophic } \\
\text { level }\end{array}$ & $\begin{array}{c}\text { Conversion factor } \\
\left(\mathrm{mg} \mathrm{ww.mmol} \mathrm{N}^{-1}\right)\end{array}$ & $\begin{array}{c}\text { Availability } \\
\text { coefficients } \\
a_{p} \\
(\text { calibrated })\end{array}$ \\
\hline Flagellates & $0.002-0.02^{*}$ & $0.027^{\mathrm{a}}$ & $1^{* *}$ & $720^{\mathrm{b}, \mathrm{c}}$ & $5.7710^{-4}$ \\
\hline Diatoms & $0.02-0.2^{*}$ & $0.03^{\mathrm{a}}$ & $1^{* *}$ & $720^{\mathrm{b}, \mathrm{c}}$ & 0.0054 \\
\hline Ciliates & $0.02-0.2^{*}$ & $0.025^{\mathrm{a}}$ & $2^{* *}$ & $675^{\mathrm{b}, \mathrm{c}}$ & 0.0095 \\
\hline Copepods & $0.2-3^{*}$ & $0.05^{\mathrm{a}}$ & $2.5^{* *}$ & $1000^{\mathrm{d}}$ & 0.113 \\
\hline
\end{tabular}

* arbitrarily set from Moloney and Field (1991), Jenny Huggetts (MCM), com pers - ** arbitrarily set (see text) - ${ }^{a}$ Koné et al. 2005 - ${ }^{b}$ calculated from Moloney and Field $1991-{ }^{c}$ calculated from Dow et al, 2006 - ${ }^{d}$ calculated from James 1987 
Table 5: Target biomass (in tons) used for the calibration by genetic algorithms, with their associated valid intervals (defined by min biomass and max biomass). Biomass values come from Shannon et al. (2003). When resulting from Ecopath calibration and thus not coming from literature, biomass values are followed by *. The results of the calibration of the coupled model ROMS- $\mathrm{N}_{2} \mathrm{P}_{2} \mathrm{Z}_{2} \mathrm{D}_{2}$-OSMOSE is also indicated (larval mortality per species).

\begin{tabular}{lcccc}
\hline Species & $\begin{array}{l}\text { Min biomass } \\
\text { (tons) }\end{array}$ & $\begin{array}{l}\text { Reference biomass } \\
\text { (tons) }\end{array}$ & $\begin{array}{l}\text { Max biomass } \\
\text { (tons) }\end{array}$ & $\begin{array}{l}\text { Larval mortalities } M_{0} \\
\text { (calibrated, week }\end{array}$ \\
\hline Euphausiids & 1601820 & $3203640^{*}$ & 4805460 & 0.0024 \\
\hline Anchovy & 497786 & 786143 & 1074500 & 2.1403 \\
\hline Sardine & 219512 & 460000 & 700488 & 1.8430 \\
\hline Redeye & 928122 & $1369720^{*}$ & 1811318 & 1.9215 \\
\hline Lanternfish & 788634 & $1577268^{*}$ & 2365902 & 0.5742 \\
\hline Ligthfish & 337986 & $675972^{*}$ & 1013958 & 0.9806 \\
\hline Horse mackerel & 266400 & 532800 & 799200 & 0.9594 \\
\hline Shallow w hake & 259384 & $388300^{*}$ & 517216 & 3.8767 \\
\hline Deep w hake & 325246 & $647900^{*}$ & 970554 & 3.2708 \\
\hline Snoek & 37070 & $74140^{*}$ & 111210 & 4.9063 \\
\hline Silver kob & 5200 & 10400 & 15600 & 3.3281
\end{tabular}




\section{Figures}
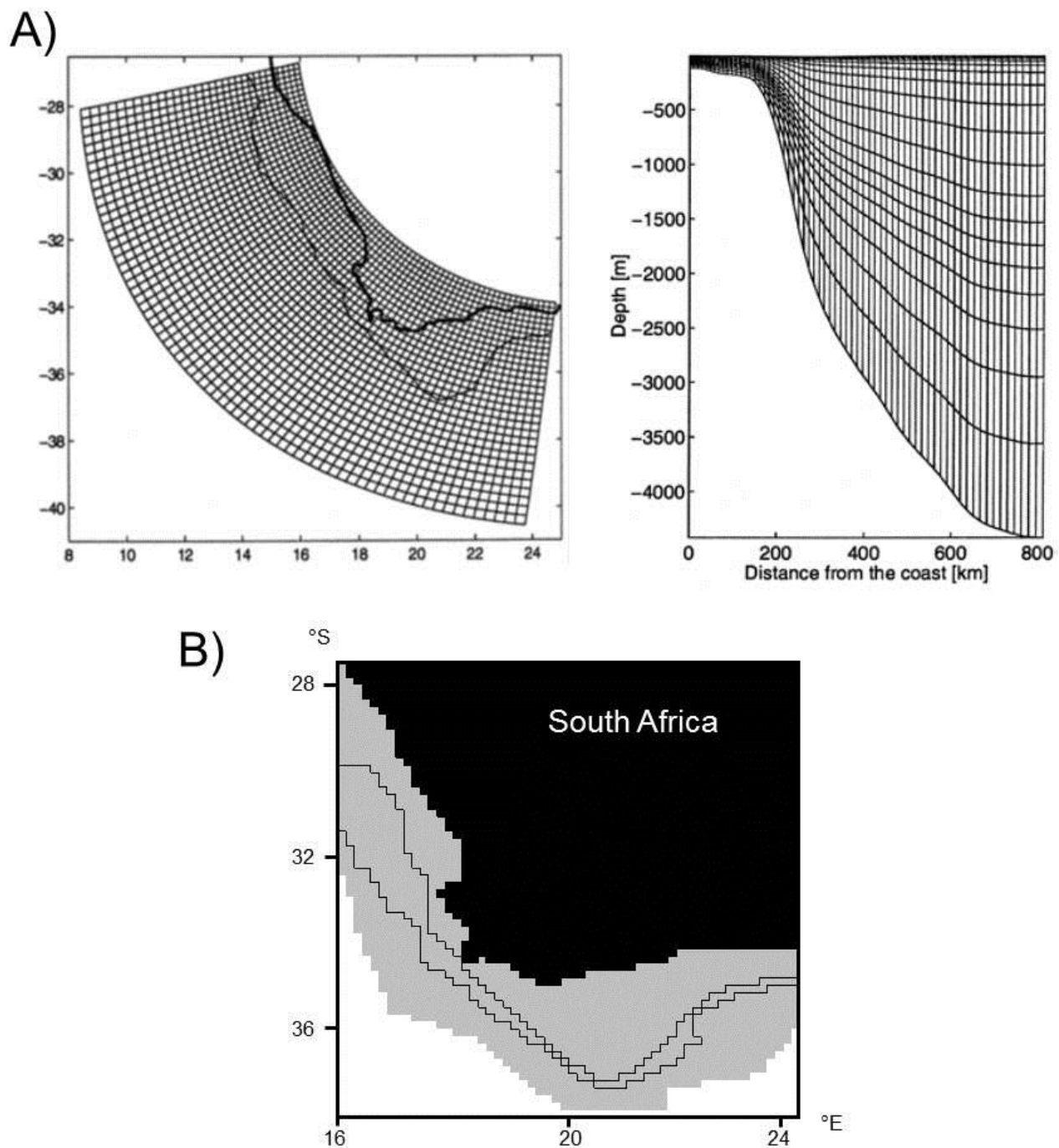

Figure 1: Grids of the sub-models used in this study. A) ROMS curvilinear grid with resolution ranging from $18 \mathrm{~km}$ near the coast to $31 \mathrm{~km}$ offshore (the coast line is marked by the bold line and the thinner line represents the $500 \mathrm{~m}$ isobath) and 20 vertical layers following the topography. B) OSMOSE square grid, divided into cells of $0.15^{\circ} \times 0.15^{\circ}$, with the isobaths $200 \mathrm{~m}$ and $500 \mathrm{~m}$ represented. The total area covered by HTL organisms, computed from the sum of distribution maps available for all species, is represented in grey. 


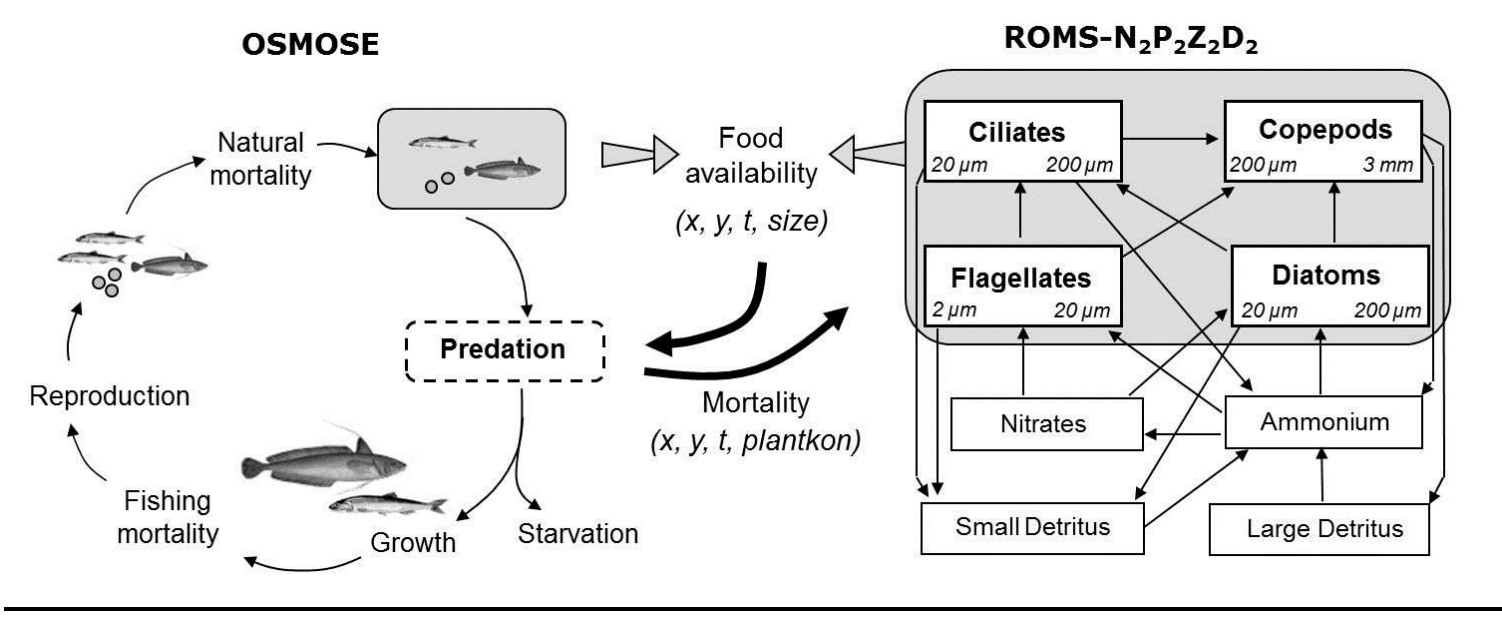

Figure 2: Principle of the two-way coupling between OSMOSE and ROMS- $\mathrm{N}_{2} \mathrm{P}_{2} \mathrm{Z}_{2} \mathrm{D}_{2}$. At each time step (t) and at each location (x,y), the biomass of phytoplankton and zooplankton is used in OSMOSE for the predation process. In OSMOSE, fish can prey upon both plankton and fish, according to predator/prey size ratios and local prey availability. The feedback consists in a predation mortality applied to plankton groups accordingly to the effective amount of plankton eaten. 


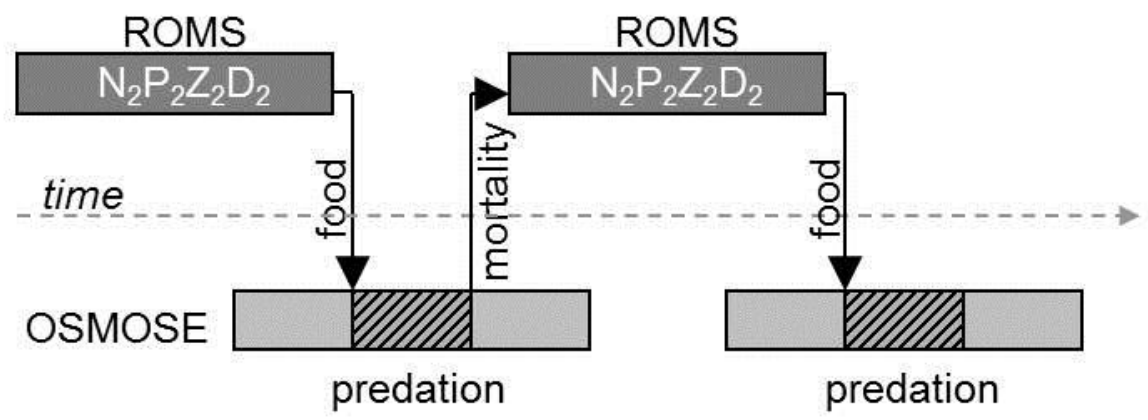

Figure 3: Scheduling of the two-way coupling between OSMOSE and ROMS- $\mathrm{N}_{2} \mathrm{P}_{2} \mathrm{Z}_{2} \mathrm{D}_{2}$. Each grey bar represents one time step of the models ( 2 weeks) and arrows representative exchange of information between models: prey field $(x, y, z)$ per plankton group from ROMS- $N_{2} P_{2} Z_{2} D_{2}$ to OSMOSE before the predation process and mortality field $(x, y)$ per plankton group from OSMOSE towards ROMS$\mathrm{N}_{2} \mathrm{P}_{2} \mathrm{Z}_{2} \mathrm{D}_{2}$ after the predation process. 


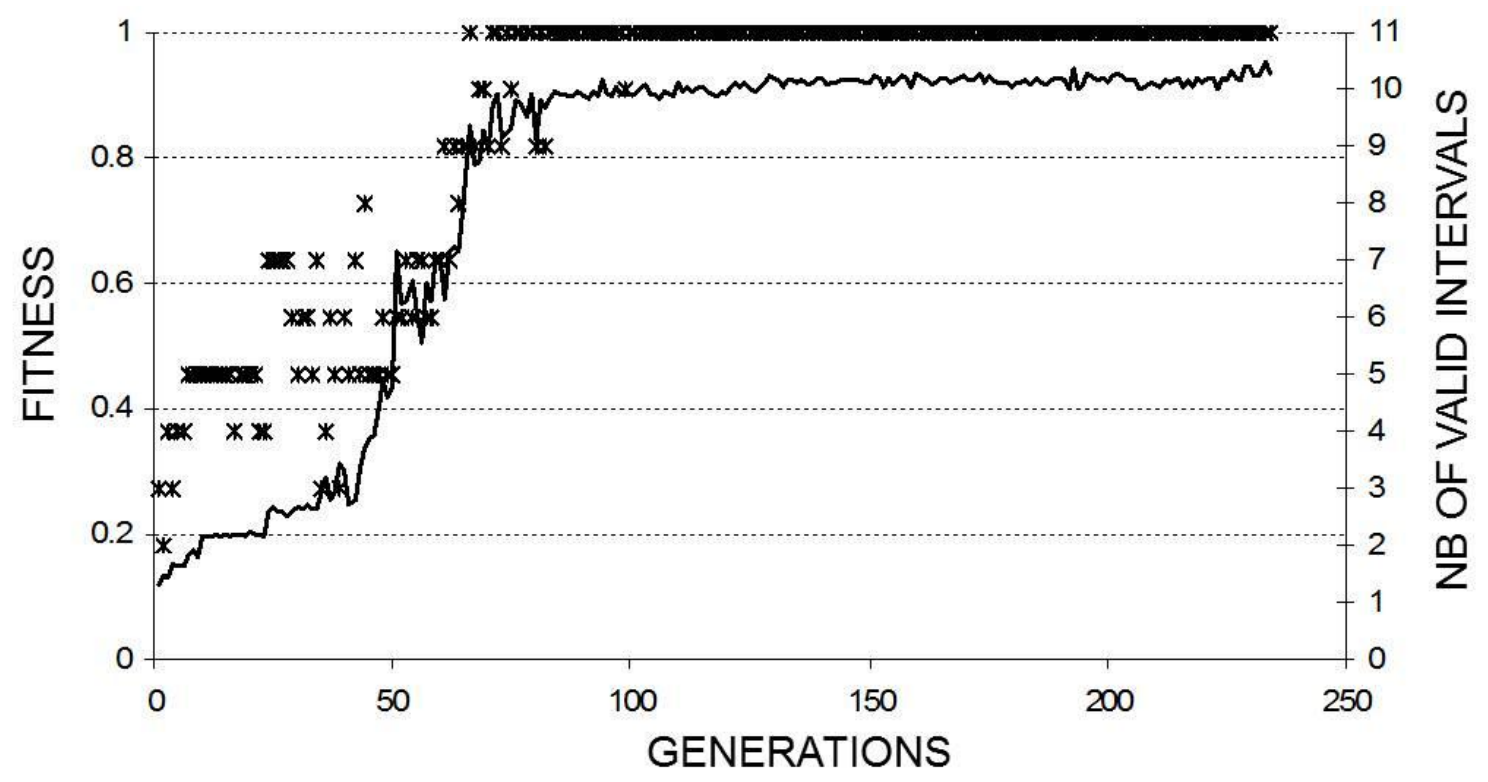

Figure 4: Fitness evolution of the best genotype found with the genetic algorithm method through generations (solid line) and evolution of the number of valid intervals found for the 11 parameters by the best genotype (stars). 

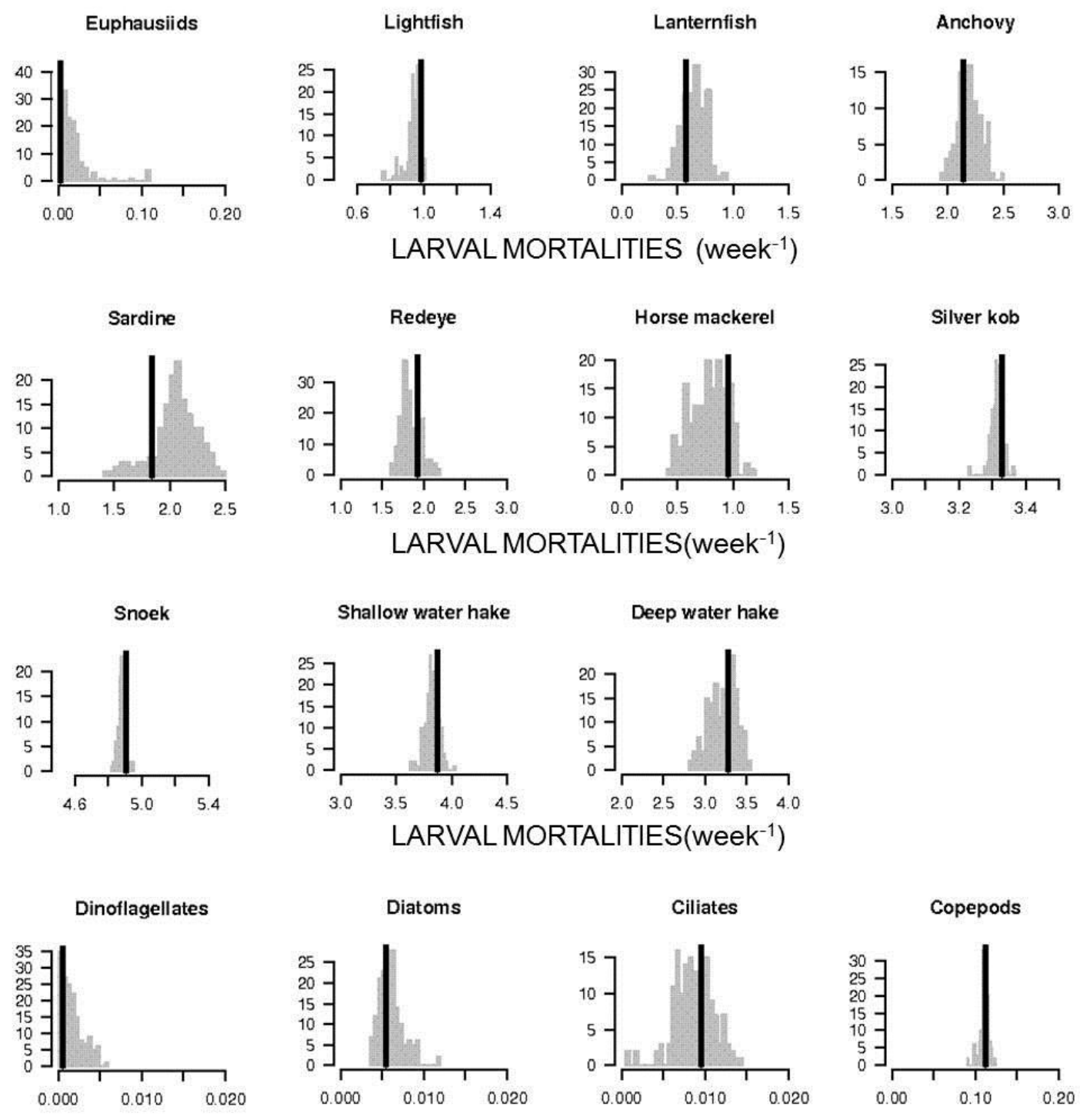

AVAILABILITY COEFFICIENTS

Figure 5: Distribution of the parameters estimates provided by the 156 best genotypes leading to the maximum number of valid intervals (11 valid intervals). The black line corresponds to the value selected for the reference simulation of the coupled model. 


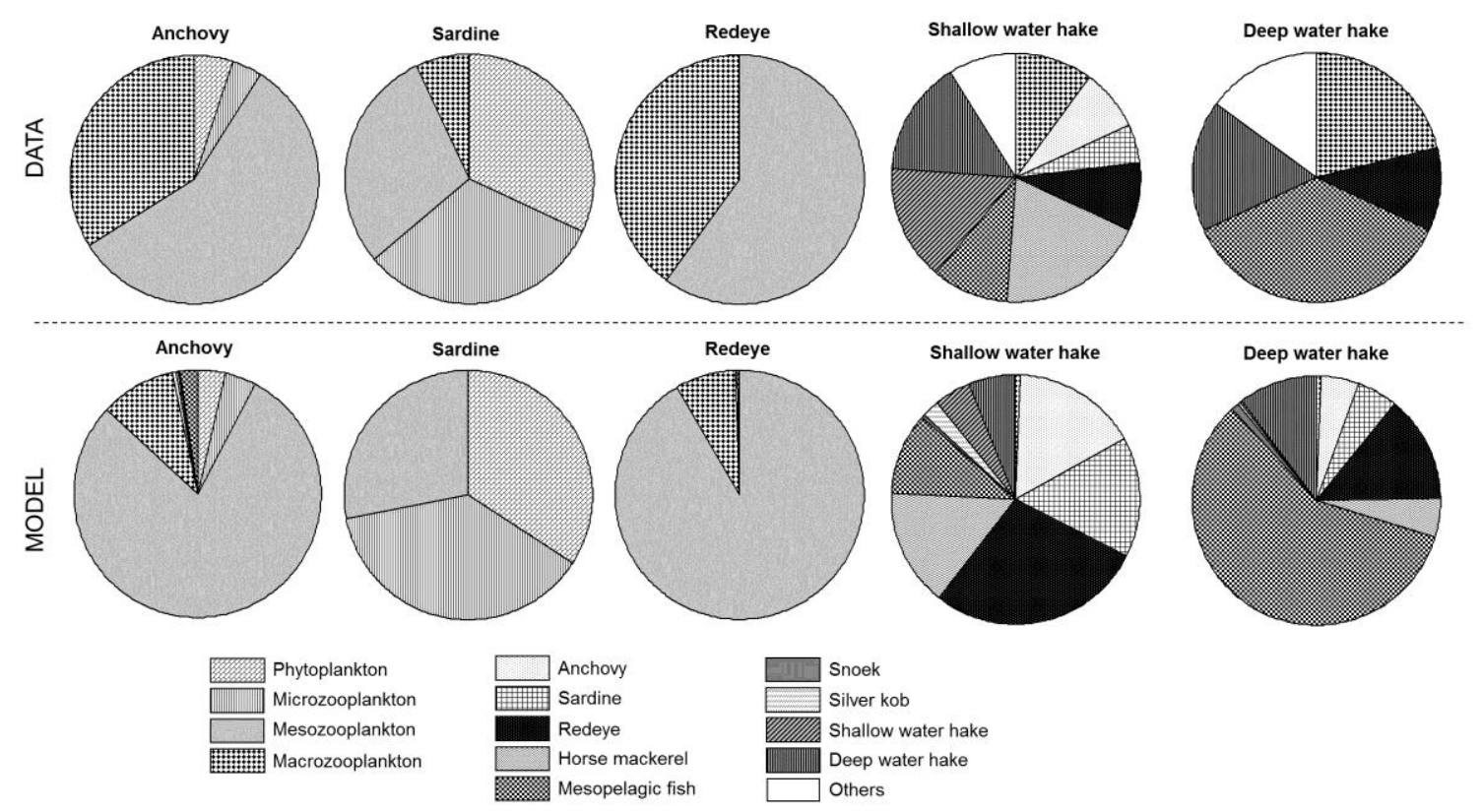

Figure 6: Above: Diets from data synthesized by Shannon et al. (2003), for the 3 main species of small pelagic fish (anchovy, sardine and redeye) and for the 2 species of Cape hake. Below: Diets simulated by the coupled model for the same species. In both cases diets are expressed as percentage of prey in mass. 

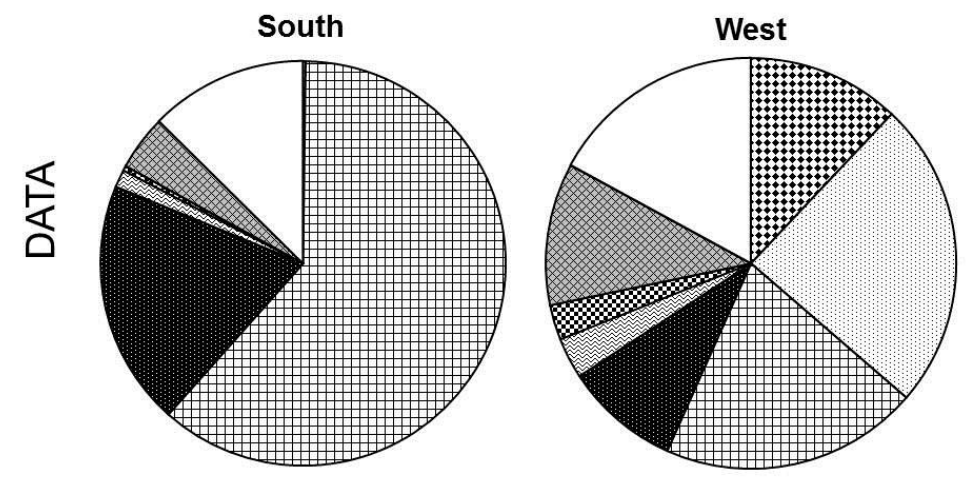

Macrozooplankton

IIy Anchovy

\# Sardine
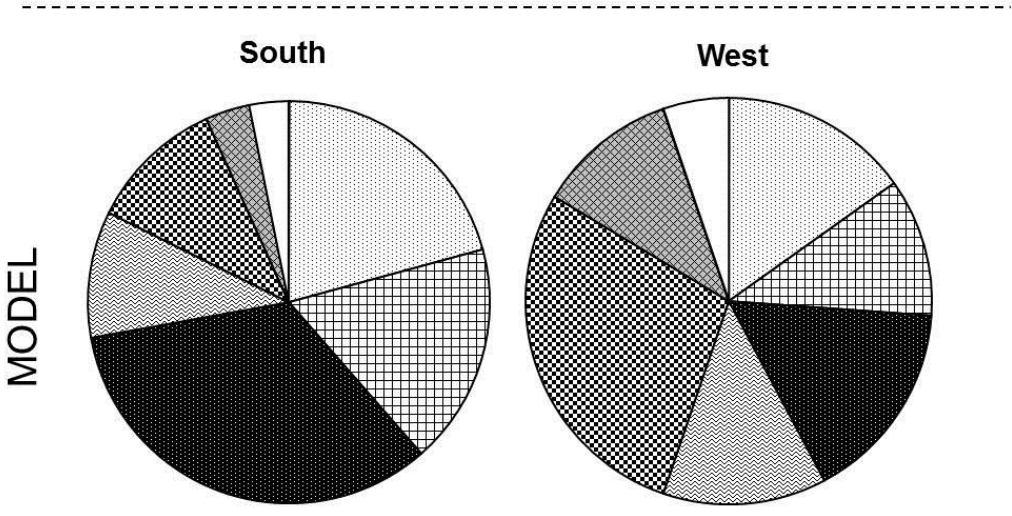

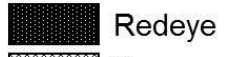

ए”.

桨䍙 Mesopelagic fish

Hake (both species)

Others

Figure 7: Diet of snoek $(50-74 \mathrm{~cm})$ from data (Griffiths 2002) and simulated by the coupled model, compared over space (South and West coast of south Africa, delimited by the $34.4^{\circ} \mathrm{S}$ latitude). Diets are expressed as percentage of prey in mass. 


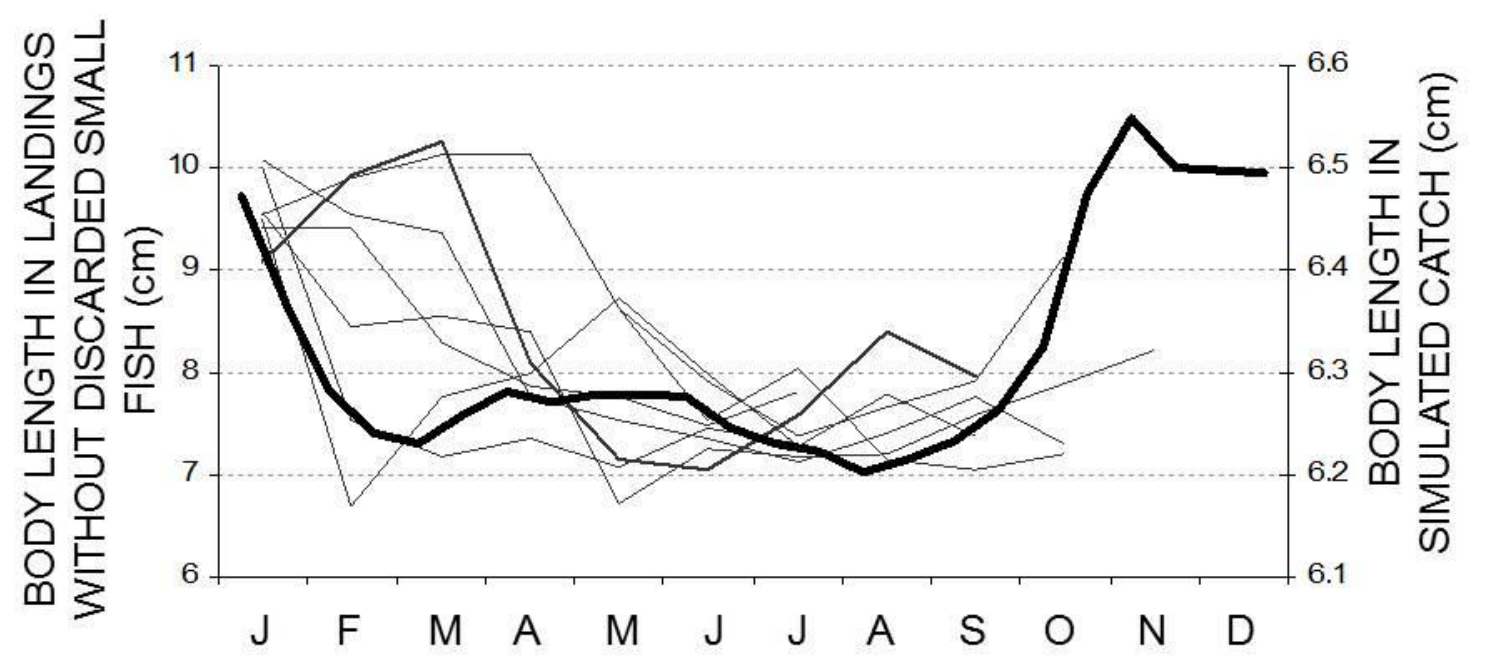

Figure 8: Evolution of the mean body size of anchovy per month in the observed landings, i.e. without discarded small-sized fish (thinner lines, data from Fairweather et al. 2006) and in the catch in the coupled model (bold line). One thin line represents the evolution of mean size during one year, and years from 1990 to 1997 are represented. 


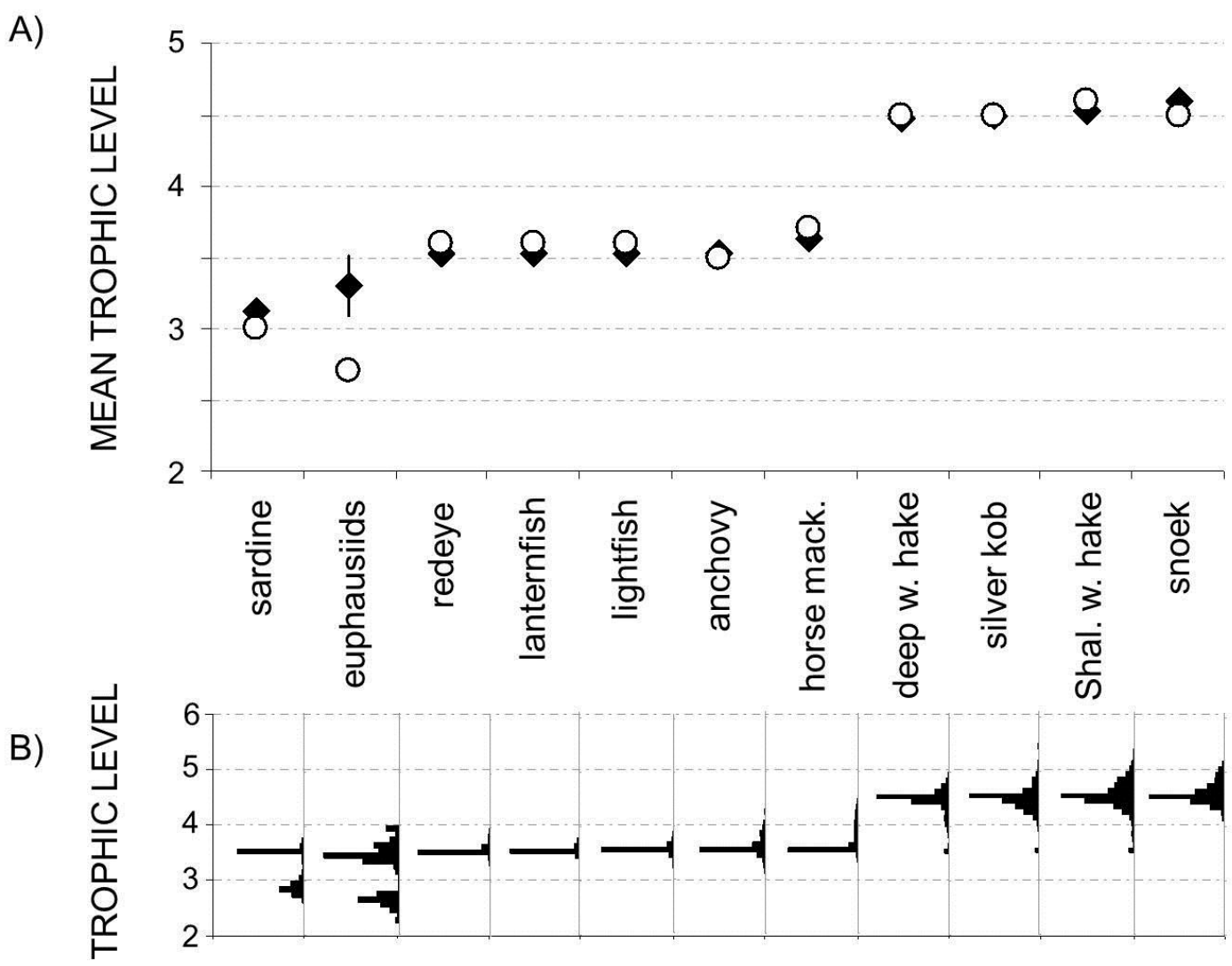

Figure 9: A) Comparison of the mean trophic levels per species in the coupled model (black diamond) and in the Ecopath model from Shannon et al. (2003) (white circle). For the coupled model, the standard deviation is indicated by a vertical bar. B) Distribution of individual trophic level for each species modelled by OSMOSE-ROMS- $\mathrm{N}_{2} \mathrm{P}_{2} \mathrm{Z}_{2} \mathrm{D}_{2}$. The distribution represents the biomass of organisms per TL class (intervals of width 0.1 from 2 to 6 ) 


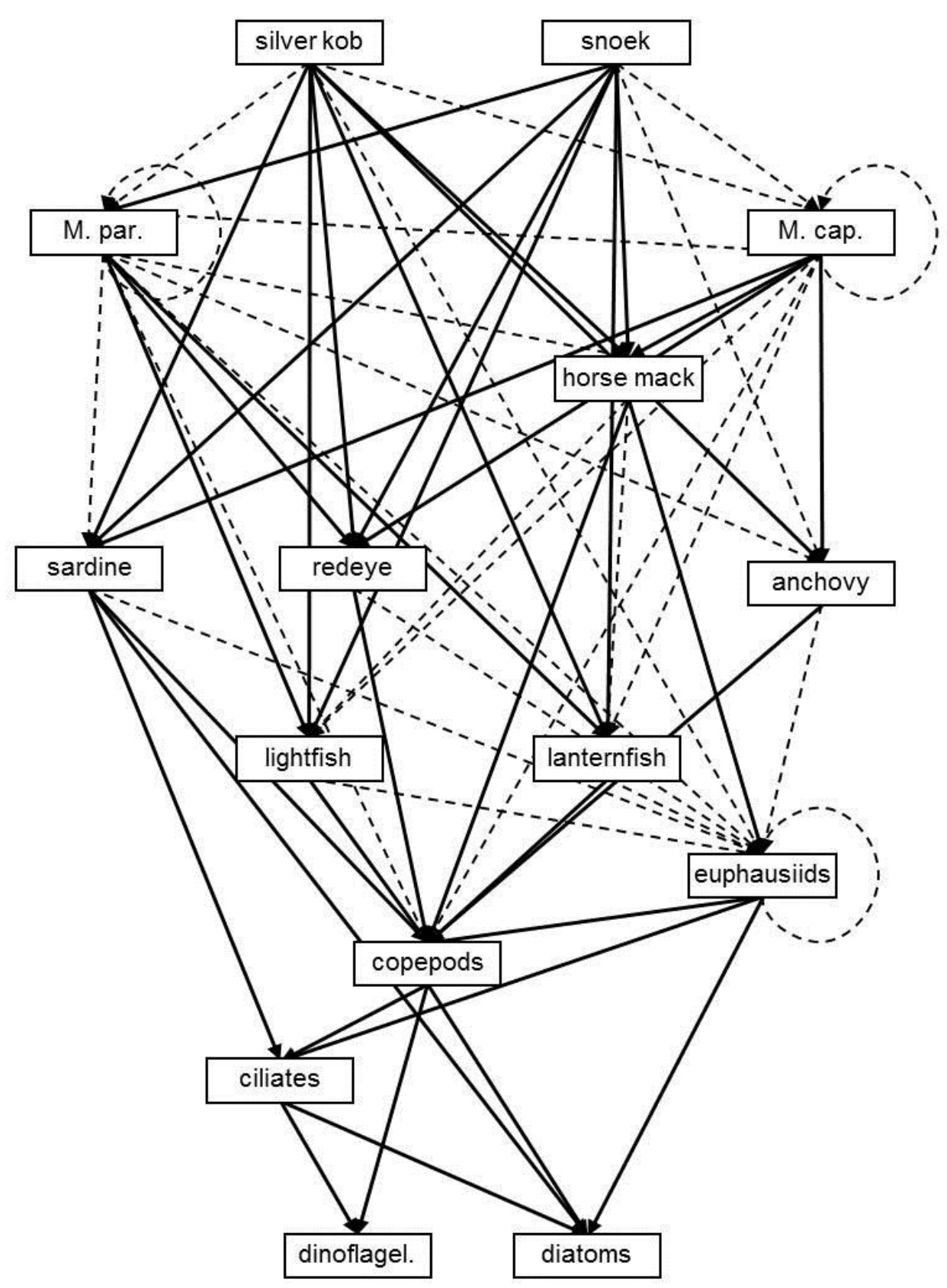

Figure 10: Representation of the modelled food web. Boxes represent species composed by all individuals older than 6 months for fish species, older than 2 months for euphausiids. Solid arrows represent links between a predator and its prey accounting for at least $10 \%$ of the diets (in mass), dashed arrow are for prey accounting from 1 to $10 \%$ of the predator diet. Trophic links less than $1 \%$ of the predators diet are not represented. Circles indicate cannibalism. 
> PAR (photosynthetically available radiation) formulation:

$$
P A R=P A R_{0} \cdot \exp \left(k_{\text {water }}+k_{\text {chla }} \cdot \theta \cdot r_{C / N, \text { phyto }} \cdot[P] \cdot \Delta z\right)
$$

where $P A R_{0}$ is the surface $P A R, k_{\text {water }}$ and $k_{C h l a}$ are attenuation coefficients for pure water and chlorophyll, $\theta$ is the chlorophyll/carbon ratio, $r_{C / N \text {,phyto }}$ is the $\mathrm{C} / \mathrm{N}$ ratio for phytoplankton, $[P]$ is phytoplankton concentration, and $\Delta z$ is the depth step.

> Nitrogen fluxes of all compartments:

$$
\begin{aligned}
& \frac{d\left[N O_{3}\right]}{d t}=-\mu_{p_{s}}\left(N O_{3}\right) \cdot \mu_{p_{s}}(P A R, T) \cdot\left[P_{s}\right]-\mu_{p_{l}}\left(N O_{3}\right) \cdot \mu_{p_{l}}(P A R, T) \cdot\left[P_{l}\right]+\mu_{A N}\left[N H_{4}\right] \\
& \frac{d\left[N H_{4}\right]}{d t}=-\mu_{p_{s}}\left(N H_{4}\right) \cdot \mu_{p_{s}}(P A R, T) \cdot\left[P_{s}\right]-\mu_{p_{l}}\left(N H_{4}\right) \cdot \mu_{p_{l}}(P A R, T) \cdot\left[P_{l}\right] \\
& +\mu_{Z_{s}} \cdot\left[Z_{s}\right]+\mu_{Z_{l}} \cdot\left[Z_{l}\right]+\mu_{D_{s}} \cdot\left[D_{s}\right]+\mu_{D_{l}} \cdot\left[D_{l}\right]-\mu_{A N} \cdot\left[N H_{4}\right] \\
& \frac{d\left[P_{s}\right]}{d t}=\mu_{p_{s}} \cdot\left[P_{s}\right]-g_{\max } \cdot g_{z_{s}}\left(P_{s}\right) \cdot\left[Z_{s}\right]-g_{\max } \cdot g_{z_{l}}\left(P_{s}\right) \cdot\left[Z_{l}\right]-m_{p_{s}}\left[P_{s}\right] \\
& \frac{d\left[P_{l}\right]}{d t}=\mu_{p_{l}} \cdot\left[P_{l}\right]-g_{\max } \cdot g_{z_{s}}\left(P_{l}\right) \cdot\left[Z_{s}\right]-g_{\max } \cdot g_{z_{l}}\left(P_{l}\right) \cdot\left[Z_{l}\right]-m_{p_{l}}\left[P_{l}\right]
\end{aligned}
$$

$$
\text { With } g_{z}(P)=\frac{e_{Z P} \cdot[P]}{k_{z}+\sum e_{z i} \cdot\left[F_{i}\right]} \text { where } \mathrm{F}_{\mathrm{i}} \text { represents all prey of } \mathrm{Z}
$$

$\frac{d\left[Z_{s}\right]}{d t}=\beta \cdot g_{z_{s}} \cdot\left[Z_{s}\right]-g_{\max } \cdot g_{z_{l}}\left(Z_{s}\right) \cdot\left[Z_{l}\right]-m_{Z_{s}} \cdot\left[Z_{s}\right]-\mu_{Z_{s}} \cdot\left[Z_{s}\right]$

$$
\frac{d\left[Z_{l}\right]}{d t}=\beta \cdot g_{z_{l}} \cdot\left[Z_{l}\right]-m_{Z_{l}} \cdot\left[Z_{l}\right]-\mu_{Z_{l}} \cdot\left[Z_{l}\right]
$$

$$
\begin{aligned}
& \frac{d\left[D_{s}\right]}{d t}=(1-\beta) \cdot g_{z_{s}} \cdot\left[Z_{s}\right]+m_{P_{s}} \cdot\left[P_{s}\right]+m_{P_{l}} \cdot\left[P_{l}\right]+m_{Z_{s}} \cdot\left[Z_{s}\right]-\mu_{D_{s}} \cdot\left[D_{s}\right] \\
& \frac{d\left[D_{l}\right]}{d t}=(1-\beta) \cdot g_{z_{l}} \cdot\left[Z_{l}\right]+m_{Z_{l}} \cdot\left[Z_{l}\right]-\mu_{D_{l}} \cdot\left[D_{l}\right]
\end{aligned}
$$

Where $P_{s}$ represents small phytoplankton (dinoflagellates), $P_{l}$ stands for large phytoplankton (diatoms), $Z_{s}$ stands for small zooplankton (ciliates), $Z_{l}$ is for large zooplankton (copepods), $D_{s}$ and $D_{l}$ are respectively for small and large detritus. Additional parameters are synthesized in the table A1. 
Table A1: Values of additional parameters (not mentioned in the text) of the $\mathrm{N}_{2} \mathrm{P}_{2} \mathrm{Z}_{2} \mathrm{D}_{2}$ biogeochemical model.

\begin{tabular}{|c|c|c|c|c|c|}
\hline Parameter & Description & Value & & Unit & Reference \\
\hline$k_{\text {water }}$ & $\begin{array}{l}\text { Light attenuation due to } \\
\text { sea water }\end{array}$ & 0.04 & & $\mathrm{~m}^{-1}$ & $\begin{array}{l}\text { Fasham et al. (1990), } \\
\text { Hurtt and Armstrong (1996), } \\
\text { Lacroix and Nival (1998), } \\
\text { Oschlies and Garçon (1999), } \\
\text { Tian et al. (2000), }\end{array}$ \\
\hline$k_{\text {Chla }}$ & $\begin{array}{l}\text { Light attenuation by } \\
\text { chlorophyll }\end{array}$ & 0.024 & & $\left(\mathrm{~m}^{2} \mathrm{mg} \mathrm{Chla}\right)^{-1}$ & Olivieri and Chavez (2000) \\
\hline$r_{C / N, \text { phyto }}$ & $\begin{array}{l}\mathrm{C} / \mathrm{N} \text { ratio for } \\
\text { phytoplankton }\end{array}$ & 6.625 & & $\operatorname{Mol~C}(\mathrm{molN})^{-1}$ & Redfield $\mathrm{C} / \mathrm{N}$ ratio $(106 / 16)$ \\
\hline$\theta$ & $\begin{array}{l}\text { Cellular chlorophyll/C } \\
\text { ratio }\end{array}$ & 0.020 & & $\begin{array}{l}\text { Mg Chla (mg } \\
\quad \mathrm{C}^{-1}\end{array}$ & $\begin{array}{l}\text { Fasham et al. (1990), } \\
\text { Lacroix and Nival (1998), } \\
\text { Tian et al. (2000), }\end{array}$ \\
\hline$\beta$ & Assimilation coefficient & $\begin{array}{l}\text { Ciliates: } \\
\text { Copepods: }\end{array}$ & $\begin{array}{l}0.75 \\
0.70\end{array}$ & n.d. & $\begin{array}{l}\text { Oschlies and Garçon (1999) } \\
\text { Olivieri and Chavez (2000) } \\
\text { Fasham et al. (1990) Lacroix } \\
\text { and Nival (1998) }\end{array}$ \\
\hline$\mu_{z}$ & Specific excretion rate & $\begin{array}{l}\text { Ciliates: } \\
\text { Copepods: }\end{array}$ & $\begin{array}{l}0.10 \\
0.05\end{array}$ & $d^{-1}$ & $\begin{array}{l}\text { Olivieri and Chavez (2000) } \\
\text { Koné et al. (2005) }\end{array}$ \\
\hline$\mu_{D}$ & $\begin{array}{l}\text { Detrital breakdown to } \\
\mathrm{NH} 4 \text { rate }\end{array}$ & $\begin{array}{l}\text { Small Det: } \\
\text { Large Det: }\end{array}$ & $\begin{array}{l}0.1 \\
0.05\end{array}$ & $d^{-1}$ & $\begin{array}{l}\text { Doney et al. (1996), Liu et al. } \\
\text { (2002) } \\
\text { Oschlies and Garçon (1999), }\end{array}$ \\
\hline$\mu_{A N}$ & $\begin{array}{l}\text { Nitrification rate of } \mathrm{NH} 4 \\
\text { to } \mathrm{NO} 3\end{array}$ & 0.05 & & $d^{-1}$ & Koné et al. (2005) \\
\hline
\end{tabular}


$>$ Euphausiids

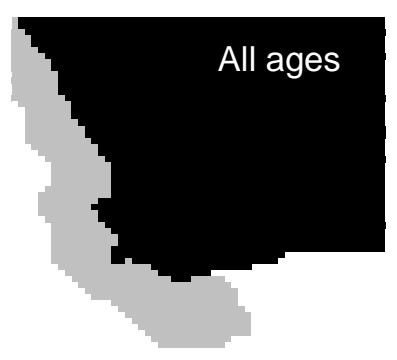

$>$ Anchovy
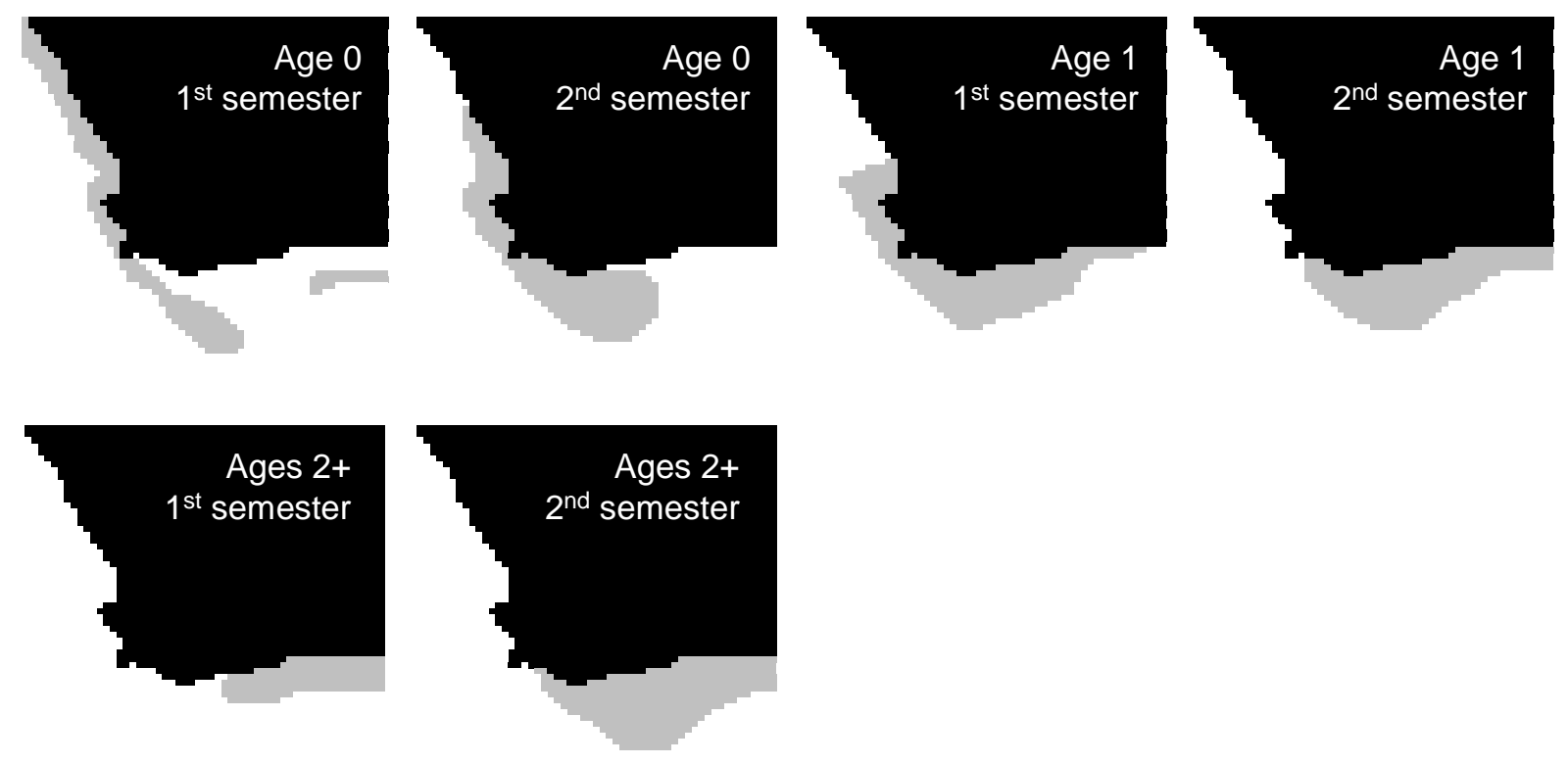

$>$ Sardine 

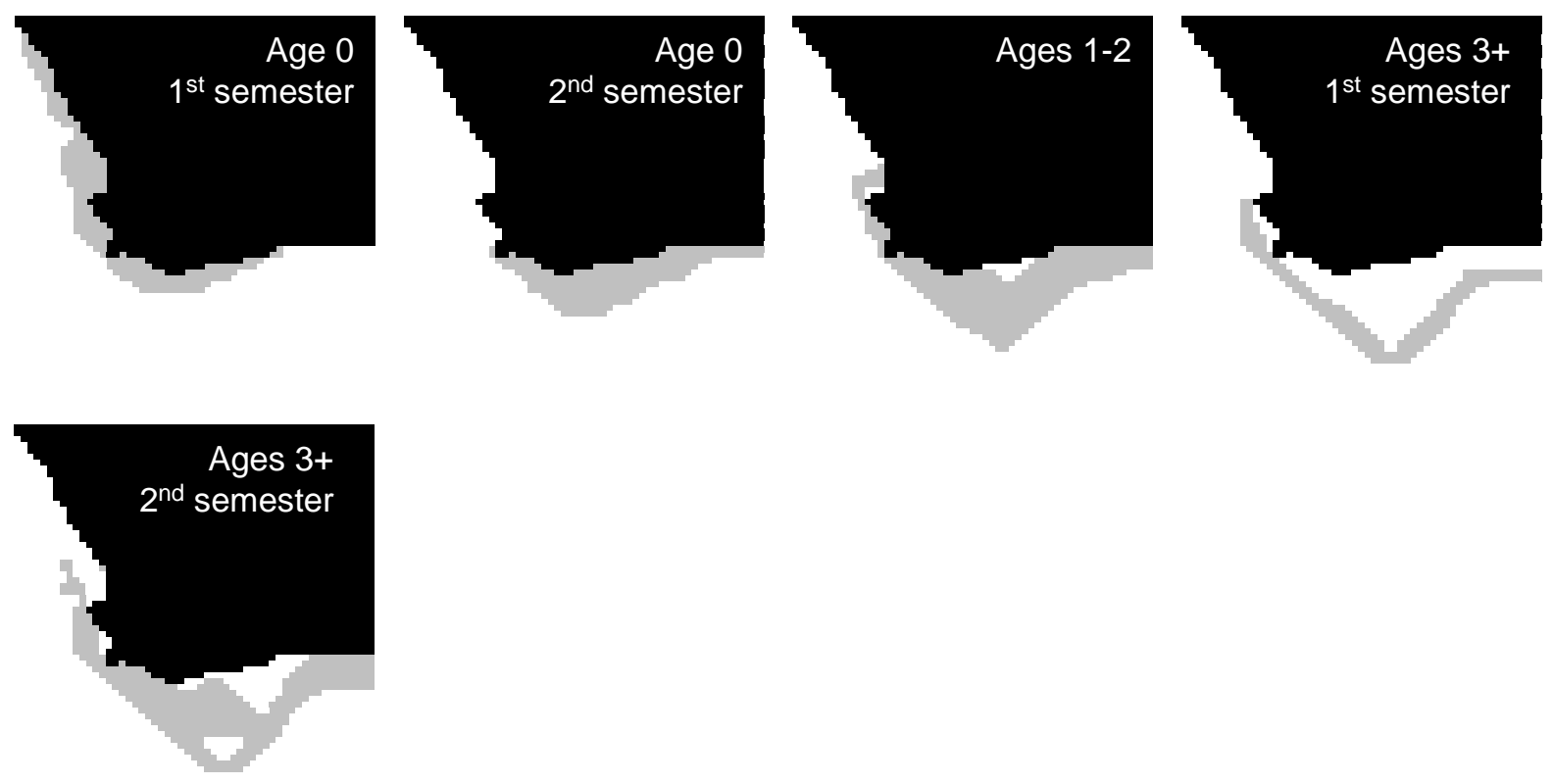

$>$ Round Herring
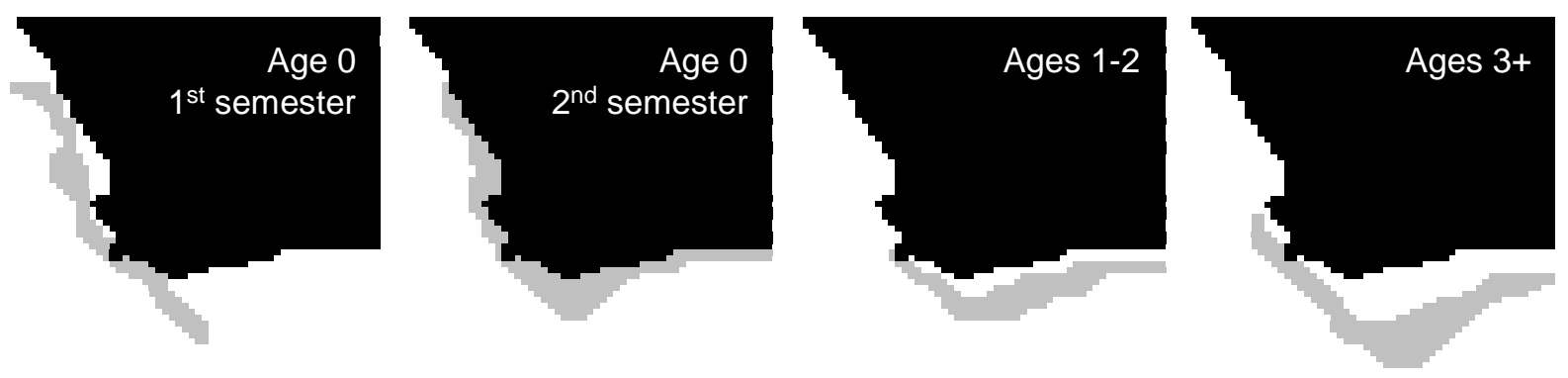

$>$ Lanternfish and lightfish
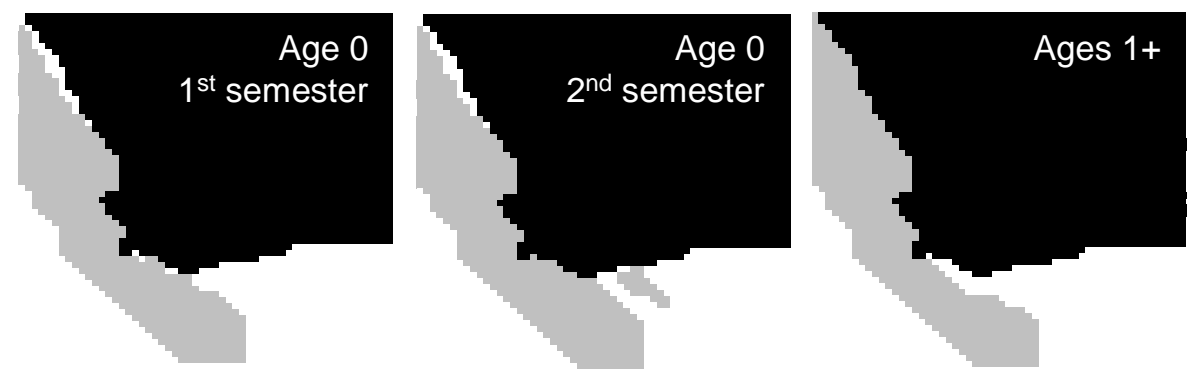

$>$ Horse mackerel 

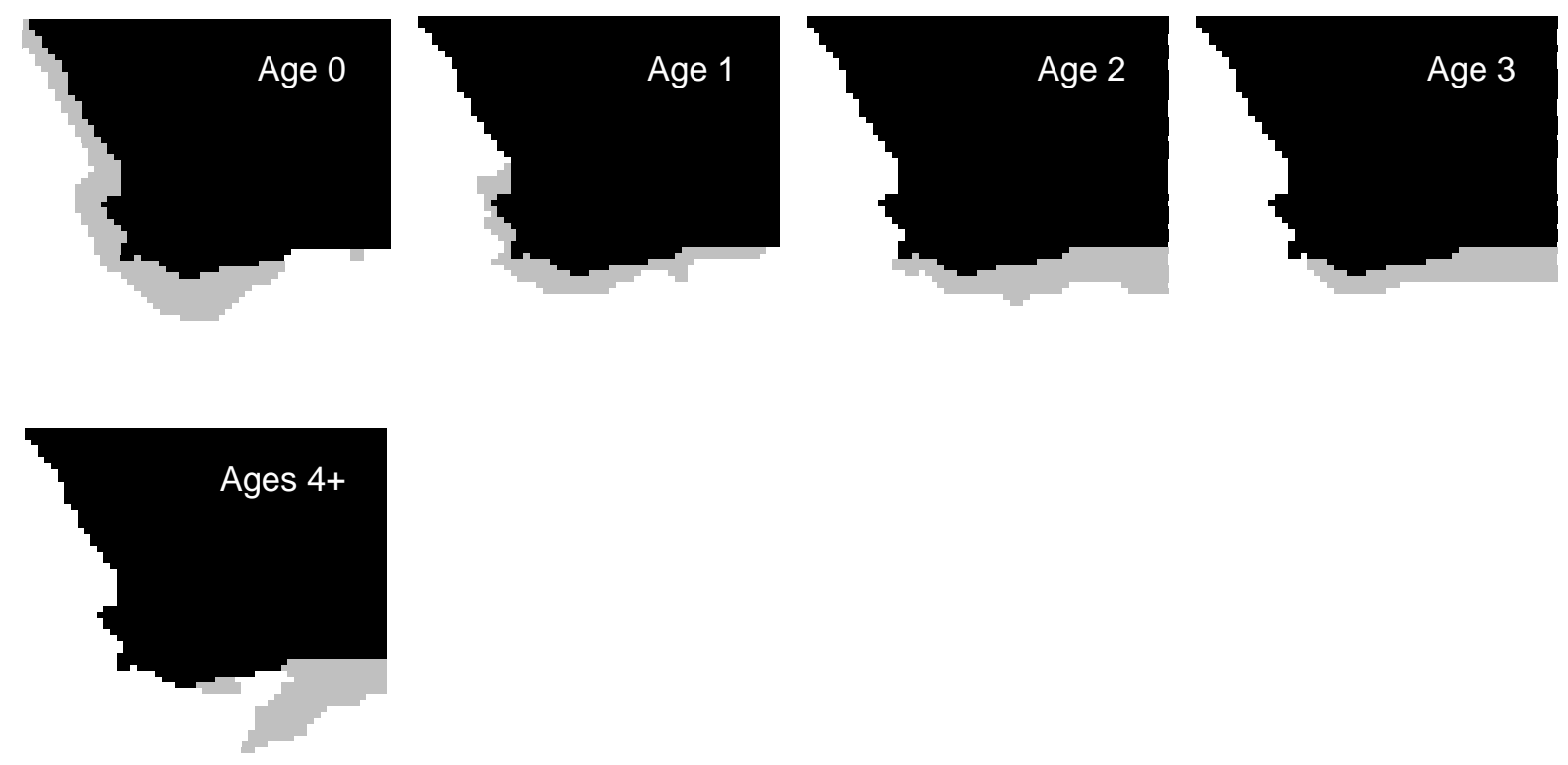

> Shallow water hake
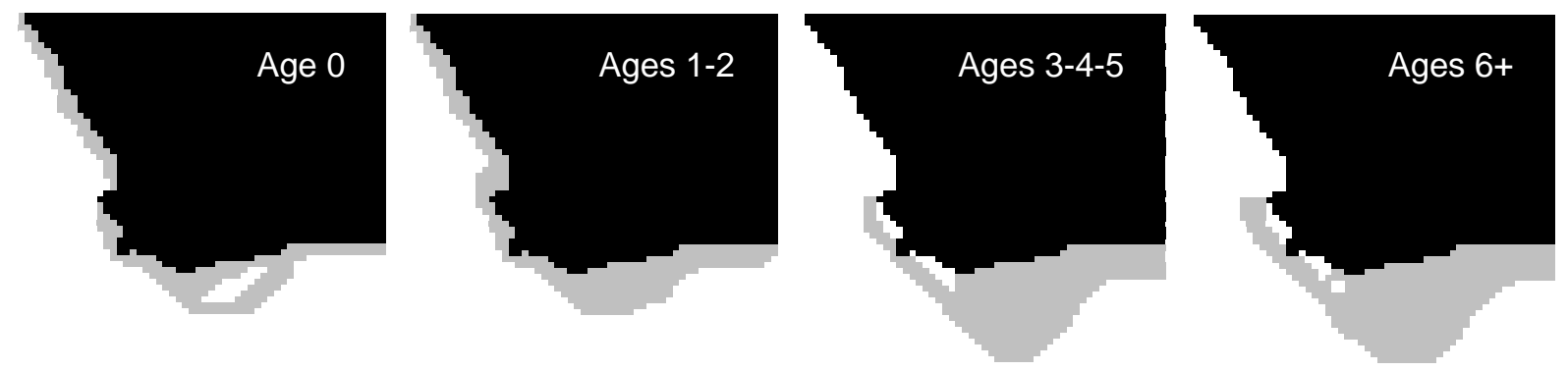

$>$ Deep water hake
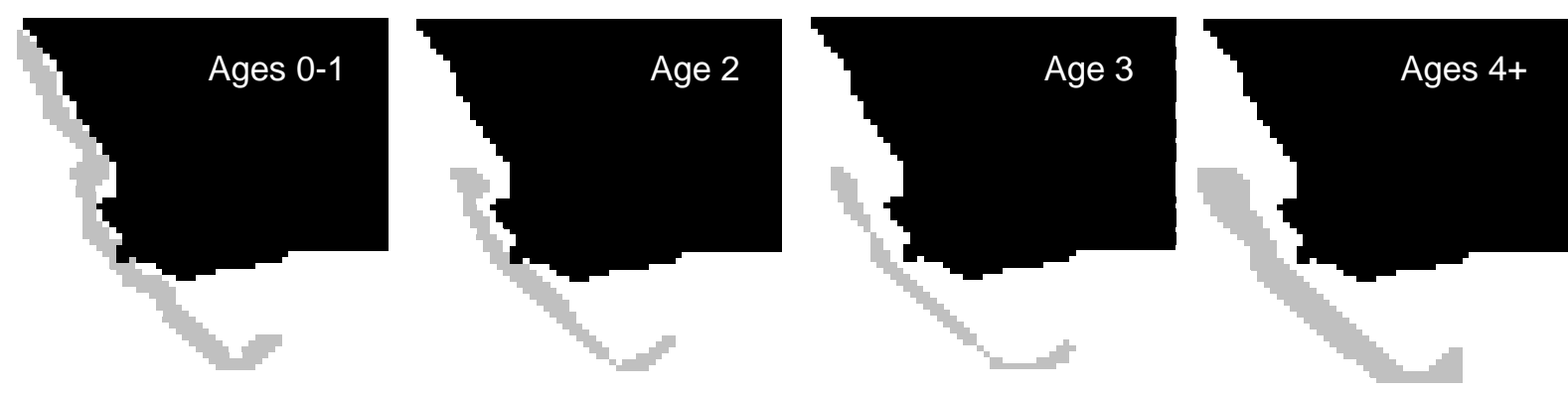

$>$ Snoek 

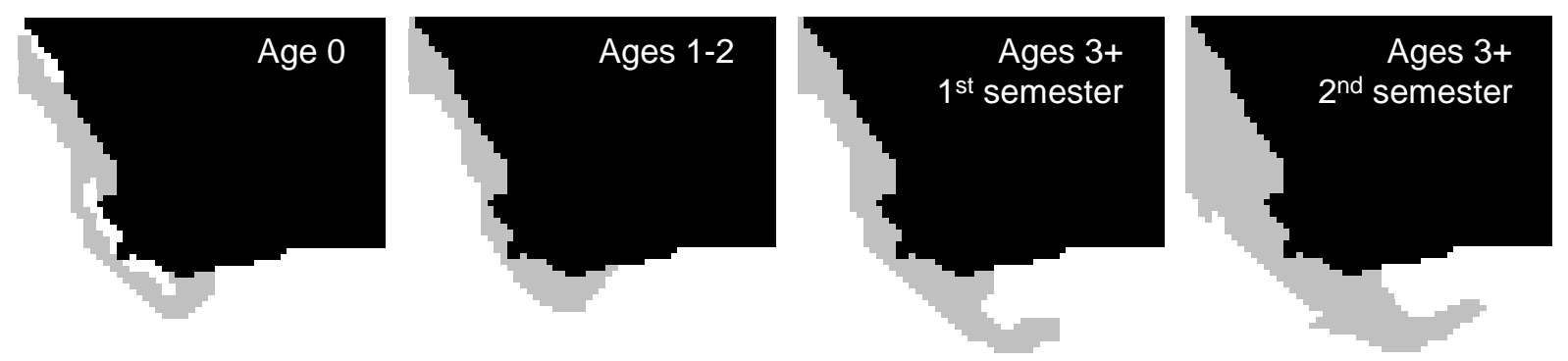

$>$ Silver kob

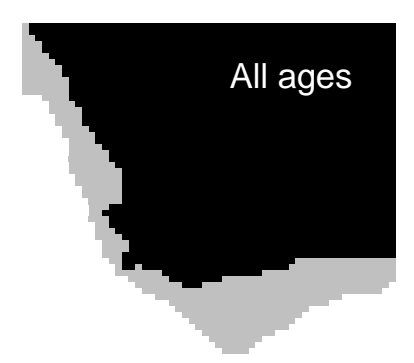

\section{Appendix C: Seasonality of fishing pressure and spawning for species modelled in OSMOSE}

Fishing seasonality: Considered constant for all species except anchovy, sardine and redeye (figure C1), either because the fishing mortality is constant over the year (Rob Leslie, pers. com.) or because no data is available.
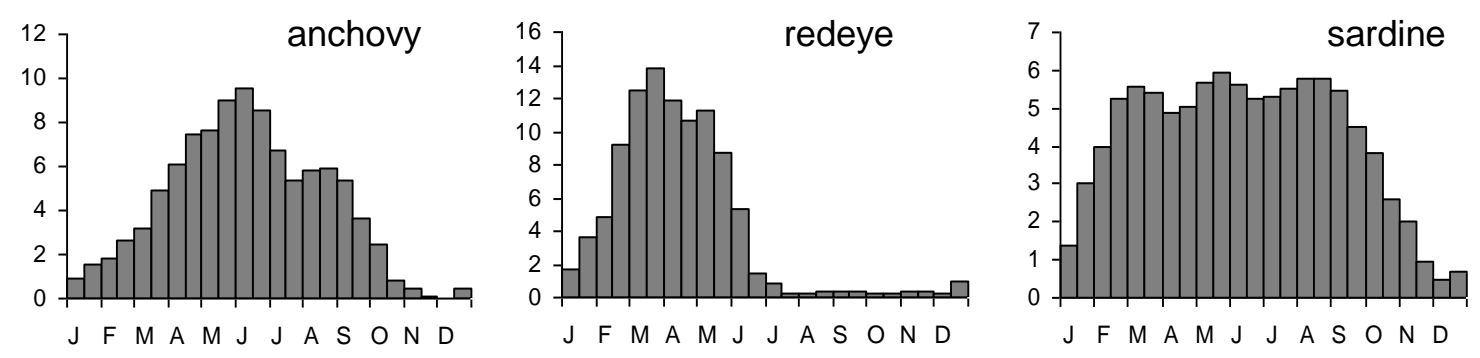

Figure $\mathrm{C} 1$ : percentage of fishing mortality per time step for anchovy, redeye and sardine (Carl van der Lingen, MCM, pers.com.). 
Spawning seasonality: Considered constant for silver kob (no data available), otherwise following the percentage per time step illustrated in figure C2.
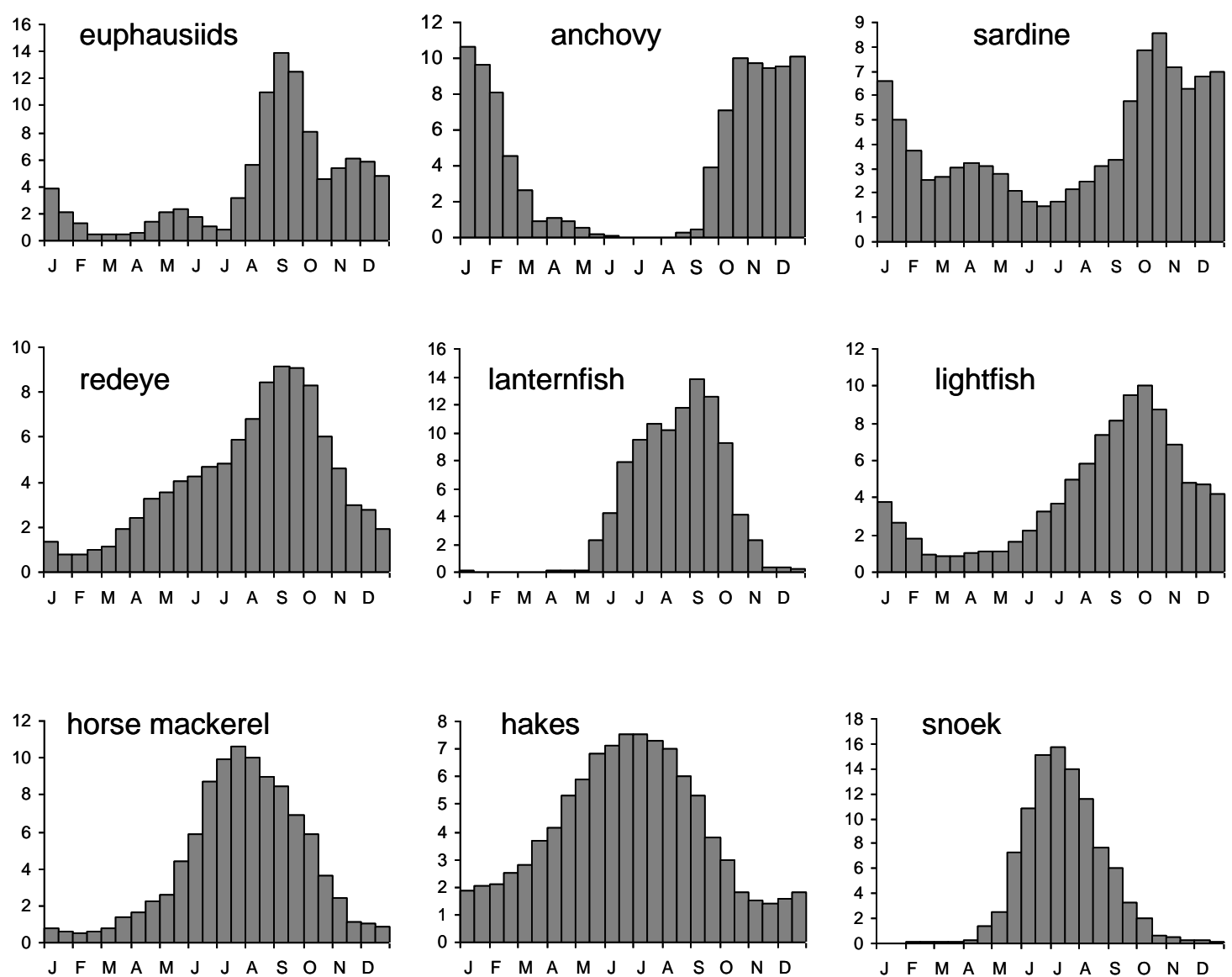

Figure C2: percentage of spawning intensity by species (derived from CELP data, Jenny Huggett, MCM, pers com) 
Appendix D: References of parameters values used for HTL organisms in OSMOSE

\begin{tabular}{|c|c|c|c|c|c|c|c|}
\hline & Growth : Linf, K, t0 & L-W allometric relation & Reproduction $: \varphi, a_{\operatorname{mat}}, a_{\max }$ & Survival & Feeding size range & $\begin{array}{c}\text { Predation } \\
\text { parameters }\end{array}$ & Spatial distribution \\
\hline Euphausiids & Pillar 1987 & Pillar 1987 & Pillar 1987 & - & $\begin{array}{c}\text { Pillar 1987, } \\
\text { Pillar et al., } 1992\end{array}$ & & Pillar et al. 1992 \\
\hline Anchovy & Waldron et al., 1989 & $\begin{array}{l}\text { van der Westhuizen } \\
\text { (com pers) }\end{array}$ & $\begin{array}{l}\text { Melo 1994, LeClus } 1979 \\
\text { Armstrong et al., } 1991\end{array}$ & $\begin{array}{l}\text { Armstrong et al., } 1991 \\
\text { Shannon et al., } 2003\end{array}$ & $\begin{array}{c}\text { Armstrong and } \\
\text { Thomas, 1989, James } \\
1987\end{array}$ & & $\begin{array}{l}\text { Armstrong and Thomas, } \\
\text { 1989, Armstrong et al. 1991, } \\
\text { Hampton 1987, Hampton } \\
\text { 1992, Valdes et al. 1897, } \\
\text { Shelton 1986, Crawford 1981 }\end{array}$ \\
\hline Sardine & $\begin{array}{l}\text { Baird 1977, Leslie } \\
\text { (com pers) }\end{array}$ & $\begin{array}{l}\text { van der Westhuizen } \\
\text { (com pers) }\end{array}$ & $\begin{array}{l}\text { Akkers 1995, van der } \\
\text { Lingen (com pers) } \\
\text { Akkers et al } 1996\end{array}$ & $\begin{array}{c}\text { Crawford } 1980 \\
\text { Shannon et al., } 2003\end{array}$ & $\begin{array}{l}\text { Armstrong and } \\
\text { Thomas, } 1989 \text {, }\end{array}$ & & $\begin{array}{l}\text { Armstrong and Thomas, } \\
\text { 1989, Hampton 1992, } \\
\text { Armstrong et al. } 1987\end{array}$ \\
\hline Redeye & Waldron et al., 1991 & Geldenhuys 1978 & $\begin{array}{c}\text { Baxter and Pope 1969, } \\
\text { Kosior and Strzyzewska } \\
1979 \\
\text { Roel and Melo } 1990\end{array}$ & $\begin{array}{l}\text { Roel and Armstrong. } \\
1991 \\
\text { Shannon et al., } 2003\end{array}$ & $\begin{array}{l}\text { Armstrong and } \\
\text { Thomas, 1989, }\end{array}$ & $\begin{array}{l}\text { Laevastu } \\
\text { and Larkins, } \\
1981\end{array}$ & $\begin{array}{l}\text { Armstrong and Thomas, } \\
\text { 1989, Hampton 1992, Roel } \\
\text { and Armstrong. } 1991\end{array}$ \\
\hline $\begin{array}{l}\text { Mesopelagic } \\
\text { (Lanternfish } \\
\text { \& Lightfish) }\end{array}$ & Prosch 1986 & $\begin{array}{c}\text { Haimovici and Velasco } \\
2000\end{array}$ & $\begin{array}{l}\text { Prosch } 1991 \\
\text { Prosch } 1986\end{array}$ & $\begin{array}{c}\text { Prosch } 1986 \\
\text { Shannon et al., } 2003\end{array}$ & Prosch et al. 1989 & $\begin{array}{l}\text { Gislason and } \\
\text { Helgason, } \\
1985\end{array}$ & $\begin{array}{c}\text { Prosch 1991, Prosch et al. } \\
\text { 1989, Armstrong and Prosch, } \\
\text { 1991, Hulley and Prosch } \\
\text { 1987, Prosch } 1986\end{array}$ \\
\hline $\begin{array}{l}\text { Horse } \\
\text { mackerel }\end{array}$ & Horsten 1999 & Kerstan (com pers) & $\begin{array}{c}\text { Kartas and Quignard } 1984 \\
\text { Leslie (pers com) in } \\
\text { Butterworth and Clarke } \\
\text { (1996) }\end{array}$ & $\begin{array}{c}\text { Horsten } 1999 \\
\text { Hecht } 1990 \\
\text { Shannon et al., } 2003\end{array}$ & $\begin{array}{l}\text { Smale 1992, } \\
\text { Crawford 1987, } \\
\text { Crawford 1989a, }\end{array}$ & $\begin{array}{l}\text { Longhurst and } \\
\text { Pauly, } 1987\end{array}$ & $\begin{array}{c}\text { Barange et al. 1998, } \\
\text { Crawford 1989a, Hecht 1990, } \\
\text { Badenhorst and Smale 1991, } \\
\text { Naish et al. 1991, Shelton } \\
\text { 1986 }\end{array}$ \\
\hline Cape hakes & Punt and Leslie 1991 & Payne et al. 1987 & $\begin{array}{c}\text { Kartas and Quignard } 1984 \\
\text { Punt and Leslie } 1991\end{array}$ & $\begin{array}{l}\text { Leslie (com pers) } \\
\text { Shannon et al., } 2003\end{array}$ & $\begin{array}{l}\text { Punt et al 1992, } \\
\text { Payne et al. } 1987\end{array}$ & & $\begin{array}{c}\text { Badenhorst and Smale 1991, } \\
\text { Payne 1989, Punt et al. 1992, } \\
\text { Punt } 1994\end{array}$ \\
\hline Snoek & Venidiktova 1988 & Griffiths (com pers) & $\begin{array}{l}\text { Rowling 1994, Nakamura } \\
\text { and Parin } 1993 \\
\text { Griffiths } 1997\end{array}$ & $\begin{array}{l}\text { Griffiths (com pers) } \\
\text { Shannon et al., } 2003\end{array}$ & Griffiths 2002 & & $\begin{array}{c}\text { Crawford 1989b, Crawford } \\
\text { and de Villiers 1985, Griffiths } \\
2002\end{array}$ \\
\hline Silver kob & Kirchner 1998 & Griffiths 1996 & $\begin{array}{c}\text { Battaglene and Talbot } \\
1994 \\
\text { Griffiths } 1997\end{array}$ & $\begin{array}{c}\text { Griffiths } 1997 \\
\text { Shannon et al., } 2003\end{array}$ & Same as snoek & & van der Elst, 1993 \\
\hline
\end{tabular}




\section{References}

Akkers T.R. 1995. A histological study of the reproductive system of the female pilchard, Sardinops sagax, in the Benguela current region. M.Sc. thesis, University of the western Cape.

Akkers T.R., Melo Y.C. and Veith W. 1996. Gonad development and spawning frequency of the South African pilchard Sardinops sagax during the 1993-1994 spawning season. South African Journal of Marine Science 17:183-193.

Armstrong M. J., Prosch R. M. 1991. Abundance and distribution of the mesopelagic fish Maurolicus muelleri in the southern Benguela system. South African Journal of Marine Science 10: 13-28.

Armstrong M. J., Thomas R. M. 1989. Clupeoids. In Oceans of Life off Southern Africa. Payne, A. I. L. and R. J. M. Crawford (Eds). Cape Town; Vlaeberg: 105-121.

Armstrong M. J., Berruti A., Golclough J. 1987. Pilchard distribution in South African waters, 1983-1985. In The Benguela and Camparable Ecosystems. Payne, A. I. L., Gulland, J. A. and K. H. Brink (Eds). South African Journal of Marine Science 5: 871-886.

Armstrong M.J., James A.G. and Valdes Szeinfeld E.S. 1991. Estimates of annual consumption of food by anchovy and other pelagic fish species off South Africa during the period 19841988. South African Journal of Marine Science 11: 251-266.

Badenhorst A., Smale M.J. 1991. The distribution and abundance of seven commercial trawlfish from the Cape south coast of South Africa, 1986-1990. South African Journal of Marine Science 11: 377-393.

Baird D. 1977 - Age, growth and aspects of reproduction of the mackerel, Scomber japonicus, in South African waters (Pices:Scombridae). Zoologica Africana 12(2): 347-362.

Barange M., Pillar S. C., Hampton I. 1998. Distribution patterns, stock size and life-history strategies of Cape horse mackerel Trachurus trachurus capensis, based on bottom trawl and acoustic surveys. In Benguela Dynamics: Impacts of Variability on Shelf-Sea Environments 
and their Living Resources. Pillar, S. C., Moloney, C. L., Payne, A. I. L. and F. A. Shillington (Eds). South African Journal of Marine Science 19: 433-447.

Battaglene S.C. and Talbot R.B. 1994. Hormone induction and larval rearing of mulloway, Argyrosomus hololepidotus (Pisces: Sciaenidae). Aquaculture 126: 73-81.

Baxter I. G. and Pope J.A. 1969. Annual variation in fecundity of Clyde spring spawning herring. ICES C.M. 1969 / H: 33.

Butterworth D.S. and Clarke E.D. 1996. Calculation of the proportion of a recent biomass estimate that should be taken to provide a precautionary maximum catch limit for horse mackerel. WG/10/96/D:HM 28.

Crawford R.J.M. 1980. Seasonal patterns in South Africa's Western Cape purse-seine fishery. Journal of Fish Biology 16: 649-664.

Crawford R. J. M. 1981. Distribution, availability and movements of anchovy Engraulis capensis off South Africa, 1964-1976. Fisheries Bulletin (South Africa) 14: 51-94.

Crawford R. J. M. 1987. Food and population variability in five regions supporting large stocks of anchovy, sardine and horse mackerel. In The Benguela and Comparable Ecosystems. Payne, A. I. L., Gulland, J. A. and K. H. Brink (Eds). South African Journal of Marine Science 5: 735-757.

Crawford R. J. M. 1989a. Horse mackerels and saury. In Oceans of Life off Southern Africa. Payne, A. I. L. and R. J. M. Crawford (Eds). Cape Town; Vlaeberg: 122-129.

Crawford R. J. M. 1989b. Snoek and chub mackerel. In Oceans of Life off Southern Africa. Payne, A. I. L. and R. J. M. Crawford (Eds). Cape Town; Vlaeberg: 177-187.

Crawford R. J. M., De Villiers G. 1985. Snoek and their prey - interrelationships in the Benguela upwelling system. South African Journal of Science 81(2): 91-97.

Doney S. C., Glover D. M., Najjar R. G. 1996. A new coupled, onedimensional biological-physical model for the upper ocean: Applications to the JGOFS Bermuda Atlantic Time-series Study (BATS) site, Deep Sea Research Part I/ 43: 591-624.

Fasham M. J. R., Ducklow H. W., McKelvie S. M. 1990. A nitrogen-based model of plankton dynamics in the oceanic mixed layer, Journal of Marine Research 48: 591-639. 
Geldenhuys N.D. 1978. Age determination of the South African round herring Etrumeus micropus and length and age composition of the commercial catches, 1965-1973. Investigational Report Sea Fisheries South Africa. 115, 1-16.

Gislason H., Helgason T. 1985. Species interaction in assessment of fish stocks with special application to the North Sea. Dana 5, 1-44.

Griffiths M.H. 1996. Age and growth of South African silver kob Argyrosomus inodorus (Sciaenidae), with evidence for separate stocks. South African Journal of Marine Science 17: 37-48.

Griffiths M.H. 1997. The life history and stock separation of silver kob, Argyrosomus inodorus, in South African waters. Fishery Bulletin 95: 45-67.

Griffiths M. H. 2002. Life history of South African snoek, Thyrsites atun (Pisces: Gempylidae): a pelagic predator of the Benguela ecosystem. Fishery Bulletin 100: 690-710.

Haimovici M. and Velasco G. 2000. Length-weight relationships of marine fishes from southern Brazil. Naga 23(1):19-23.

Hampton I. 1987. Acoustic study on the abundance and distribution of anchovy spawners and recruits in South African waters. In The Benguela and Comparable Ecosystems. Payne, A. I. L., Gulland, J. A. and K. H. Brink (Eds). South African Journal of Marine Science 5: 901-917.

Hampton I. 1992. The role of acoustic surveys in the assessment of pelagic fish resources on the South African continental shelf. In Benguela Trophic Functioning. Payne, A. I. L., Brink, K. H., Mann, K. H. and R. Hilborn (Eds). South African Journal of Marine Science 12: 1031-1050.

Hecht T. 1990. On the life history of Cape horse mackerel Trachurus trachurus off the South-East Coast of South Africa. South African Journal of Marine Science 9: 317-326.

Horsten M.B. 1999. An age-structured production model for South African horse mackerel, Trachurus capensis. WG/APR99/PEL/11.

Hulley P. A., Prosch R.M. 1987. Mesopelagic fish derivatives in the southern Benguela upwelling region. In The Benguela and Comparable Ecosystems. Payne, A. I. L., Gulland, J. A. and K. H. Brink (Eds). South African Journal of Marine Science 5: 597-611. 
Hurtt G. C., Armstrong R.A. 1996. A pelagic ecosystem model calibrated with BATS data, Deep Sea Research Part I/ 43: 653-683.

James A.G. 1987. Feeding Ecology, diet and field-based studies on feeding selectivity of the Cape anchovy Engraulis capensis Gilchrist. In: Payne, A.I.L., Gulland, J.A., Brink, K.H. (eds), The Benguela and comparable ecosystems. South African Journal of Marine Science

5, 673-692. Kartas, F. and Quignard, J.-P. 1984. La fécondité des poissons téléostéens. Paris; Masson. Collection de Biologie des Milieux Marins No. 5.

Kirchner C.H. 1998. Population dynamics and stock assessment of the exploited silver kob (Argyrosomus inodorus) in Namibian waters. PhD thesis, University of Port Elizabeth.

Koné V., Machu E., Penven P., Andersen V., Garçon V., Demarcq H., Fréon P. 2005. Modelling the primary and secondary productions of the Southern Benguela upwelling system: a comparative study through two biogeochemical models. Global Biogeochemical Cycles 19: GB4021.

Kosior M., Strzyzewska K. 1979. The fecundity of Baltic herring. ICES C.M. 1979 / J.

Lacroix G., Nival P. 1998. Influence of meteorological variability on primary production dynamics in the Ligurian Sea (NW Mediterranean Sea) with a 1D hydrodynamic/biological model, Journal of Marine Systems 16: 23-50.

Laevastu T., Larkins H. 1981. Marine Fisheries Ecosystem. Its Quantitative Evaluation and Management. Farnham, England; Fishing News Books: 162 pp.

Le Clus F. 1979. Fecundity and maturity of anchovy Engraulis capensis off South West Africa. Fisheries Bulletin South Africa 11: 26-38.

Liu K.-K., Chao S.-Y., Shaw P.-T., Gong G.-C., Chen C.-C., Tang T. Y. 2002. Monsoon-forced chlorophyll distribution and primary production in the South China Sea: Observations and a numerical study. Deep Sea Research Part / 49: 1387-1412.

Longhurst A. R., Pauly D., 1987. Ecology of Tropical Oceans. San Diego; Academic Press: xi + $407 \mathrm{pp}$. 
Melo Y.C. 1994. Spawning frequency of the anchovy Engraulis capensis. South African Journal of Marine Science 14: 321- 331.

Naish K-A., Hecht T., Payne A.I.L. 1991. Growth of Cape horse mackerel Trachurus trachurus capensis off South Africa. South African Journal of Marine Science 10: 29-35.

Nakamura I. and Parin N.V. 1993. Snake mackerels and cutlassfishes of the world (Families Gempylidae and Trichiuridae). FAO Fisheries Synopsis. 15(125).

Olivieri R. A., Chavez F. P. 2000. A model of plankton dynamics for the coastal upwelling system of Monterey Bay, California, Deep Sea Research Part I/ 47: 1077- 1106.

Oschlies A., Garçon V. 1999. An eddy-permitting coupled physicalbiological model of the North Atlantic: 1. Sensitivity to advection numerics and mixed layer physics, Global Biogeochemical Cycles 13(1): 135-160.

Payne A.I.L., Rose B., Leslie R.W. 1987. Feeding of hake and a first attempt at determining their trophic role in the South African west coast marine environment. In: Payne, A.I.L., Gulland, J.A., Brink, K.H. (eds), The Benguela and Comparable Ecosystems. South African Journal of Marine Science 5: 471-501.

Payne A.I.L. 1989. Cape hakes. In: Payne, A.I.L., Crawford, R.J.M., Van Dalsen, A.P. (eds), Oceans of life off southern Africa. Vlaeberg Publishers. Cape Town. pp. 136-147.

Pillar S.C. 1987. Distribution and population dynamics of Euphausia Lucens (Euphausiacea) in the southern Benguela current. PhD Thesis, University of Cape Town.

Pillar S.C., Stuart V., Barange M., Gibbons M.J., 1992. Community structure and trophic ecology of Euphausiids in the Benguela ecosystem. In: Payne, A.I.L., Brink, K.H., Mann, K.H., Hilborn, R. (eds), Benguela Trophic Funtioning, South African Journal of Marine Science 12: 393-409.

Prosch R.M. 1986. The biology, distribution and ecology of Lampanyctodes hectoris and Maurolicus muelleri along the South-African coast. M.Sc. thesis, University of Cape Town.

Prosch R.M. 1991. Reproductive biology and spawning of the myctophid Lampanyctodes hectoris and the sternoptychid Maurolicus muelleri in the southern Benguela ecosystem. South African Journal of Marine Science 10: 241-252. 
Prosch R.M., Hulley P.A., Cruickshank R.A., 1989. Mesopelagic fish and some other forage species. In: Payne, A.I.L., Crawford, R.J.M., Van Dalsen, A.P. (eds), Oceans of life off southern Africa. Vlaeberg Publishers. Cape Town. pp. 130-135.

Punt A. E. 1994. Assessments of the stocks of Cape hakes Merluccius spp. off South Africa. South African Journal of Marine Science 14:159-186.

Punt A.E. and Leslie R. 1991. Estimates of some biological parameters for the Cape hakes off the South African West Coast. South African Journal of Marine Science 10: 271-284.

Punt A.E., Leslie R.W., du Plessis S.E. 1992. Estimation of the annual consumption of food by Cape hake Merluccius capensis and M. Paradoxus off the South African West Coast. In: Payne, A.I.L., Brink, K.H., Mann, K.H., Hilborn, R. (eds), Benguela Trophic Functioning. South African Journal of Marine Science 12: 611-634.

Roel B.A. and Armstrong M.J. 1991. The round herring Etrumeus whiteheadi, an abundant, underexploited clupeoid species off the coast of southern Africa. South African Journal of Marine Science 11: 267-287.

Roel B.A. and Melo Y.C. 1990. Reproductive biology of the round herring Etrumeus whiteheadi. South African Journal of Marine Science 9: 177-187.

Rowling K.R. 1994. Gemfish, Rexea solandri. In The South East Fishery: a scientific review with reference to quota management. Edited by Tilzey, R.D.J. Bureau of Resource Sciences, Australian Government Print Service. Canberra. pp. 115-123.

Shannon L. J., Moloney C. L., Jarre A., and Field J. G. 2003. Trophic flows in the southern Benguela during the 1980s and 1990s. Journal of Marine Systems 39: 83-116.

Shelton P. A. 1986. Fish spawning strategies in the variable southern Benguela Current region.

Ph.D. thesis, University of Cape Town: [vi] + 327 pp.

Smale M.J. 1992. Predatory fish and their prey - an overview of trophiq interactions in the fish communities of the west and south coasts of South Africa. In: Payne, A.I.L., Brink, K.H., Mann, K.H., Hilborn, R. (eds), Benguela Trophic Functioning. South African Journal of Marine Science 12: 803-821. 
Tian R. C., Vézina A., Legendre L., Ingram R.G., Klein B., Packard T., Roy S., Savenkoff C., Silverberg N., Therriault J.C., Tremblay J.E. 2000. Effects of pelagic food-web interactions and nutrient remineralization on the biogeochemical cycling of carbon: A modeling approach. Deep Sea Research Part I/ 47: 637-662.

Valdés E. S., Shelton P. A., Armstrong M. J., Field J. G., 1987. Cannibalism in South African anchovy: egg mortality and egg consumption rates. In The Benguela and Comparable Ecosystems. Payne, A. I. L., Gulland, J. A. and K. H. Brink (Eds). South African Journal of Marine Science 5: 613-622.

Van der Elst, R. 1993. A Guide to the Common Sea Fishes of Southern Africa. Cape Town; Struik: 398 pp.

Venidiktova L.I. 1988. On age determination methods for snoek (Thyrsites atun Eupr. 1791) from the southeast Atlantic, rate of growth and von Bertalanffy growth parameters. Collection of Scientific Papers ICSEAF. pp. 283-288.

Waldron M.E., Prosch R.M. and Armstrong M.J. 1991. Growth of juvenile round herring Etrumeus whiteheadi in the Benguela system. South African Journal of Marine Science 10: 83-89.

Waldron M., Armstrong M.J. and Prosch R.M. 1989. Aspects of variability in growth of juvenile anchovy Engraulis capensis in the southern Benguela system. South African Journal of Marine Science 8: 9-19. 